Received: 17 November 2020 Accepted: 28 November 2020

Keywords: Pianist Fernando Guzmán classical musicians Guzmán; Guzmán family of pianists, Guzmán slaves; musician slaves; Afro-descendant musicians

\section{The Guzmán's of Mendoza - acclaimed classical musicians}

\author{
William M. Guzman
}

Abstract: During the $19^{\text {th }}$ century in Chile and for three generations, the Guzmán's were acclaimed classical musicians. The literature indicates that their patriarch Fernando Guzmán and his son Francisco arrived in Chile from Mendoza, Argentina in about 1822. There is little or no information regarding their heritage, origins and the correct composition of their large family. There are many errors and assumptions in the literature as to the number and paternity of several of them; it is intended to correct the misinformation and provide documentary evidence of the family origins, heritage and composition. The research makes use of the Mendoza Baptisms, Marriages and Deaths Parish Books from the $18^{\text {th }}$ and $19^{\text {th }}$ centuries, legal documents, and published material. It is confirmed that Fernando Guzmán was born into slavery, one of five children of Maria Juana, an African slave owned by the Santo Domingo Convent of Mendoza. Fernando married Juana Agustina, also a slave of African descent, owned by the Molina Sotomayor family. Fernando and Juana Agustina had 13 children, several of whom were also born into slavery. The Guzmán's were a family of classical musicians par excellence. To celebrate their life and work, this research identifies and reports how the family was composed and how it evolved.

\title{
Introduction
}

During the $19^{\text {th }}$ century and for three generations, the Guzmán's were acclaimed classical musicians, soloists and music pedagogues, becoming involved in the facets of the nascent musical environment, first in Mendoza and then in Chile, after their arrival there in the 1820s. Their patriarch, Fernando Guzmán, was the head of the large family of the future musicians; he was a pianist, organist, violinist and a teacher of music.

The literature indicates that Fernando Guzmán and his son Francisco arrived in Chile from Mendoza in 1822, or soon after. No mention is made of their heritage, origins or the composition of the family, only that they arrived from Mendoza. There is no mention either of how Fernando became a pianist, organist, violinist, and a music teacher.

But there is more to the story that was left behind in Mendoza. In the last 15 years, the literature indicates the issue of slavery in relation to Fernando Guzmán. It is now known and confirmed, that Fernando Restituto, as he was named then, was born into slavery, one of five children of Maria Juana, an African slave, owned by the Dominican Convent of Mendoza.

Fernando Restituto was self-taught in music, beginning to play the piano and violin at an early age at the Convent where he was born. By 1790, age 12, Fernando was giving concerts at parties of the most affluent families of Mendoza. As he grew older, Fernando Restituto received tutelage from Pedro Bebelaqua, an Italian musician who came to Mendoza in about $1796 .{ }^{1}$ The literature indicates that Pedro's specialty instrument was the flute; he knew to read and write music.

By the early 1800s Fernando was teaching piano to private students in Mendoza. Fernando was also earning his keep by playing the organ during Church ceremonies. An invoice has been found from 1806, that indicates that Fernando played the organ at the funeral of José Antonio Amigorena. The invoice was found with the documents of Bruno Morón, the Executor of the Will of the deceased Amigorena. ${ }^{2}$ The invoice, 
signed by Fernando, charged 3 pesos for playing the organ over several days during the prayer vigil and the funeral of the deceased. Figure 1 below presents Fernando Guzmán's invoice dated 14 January 1806:

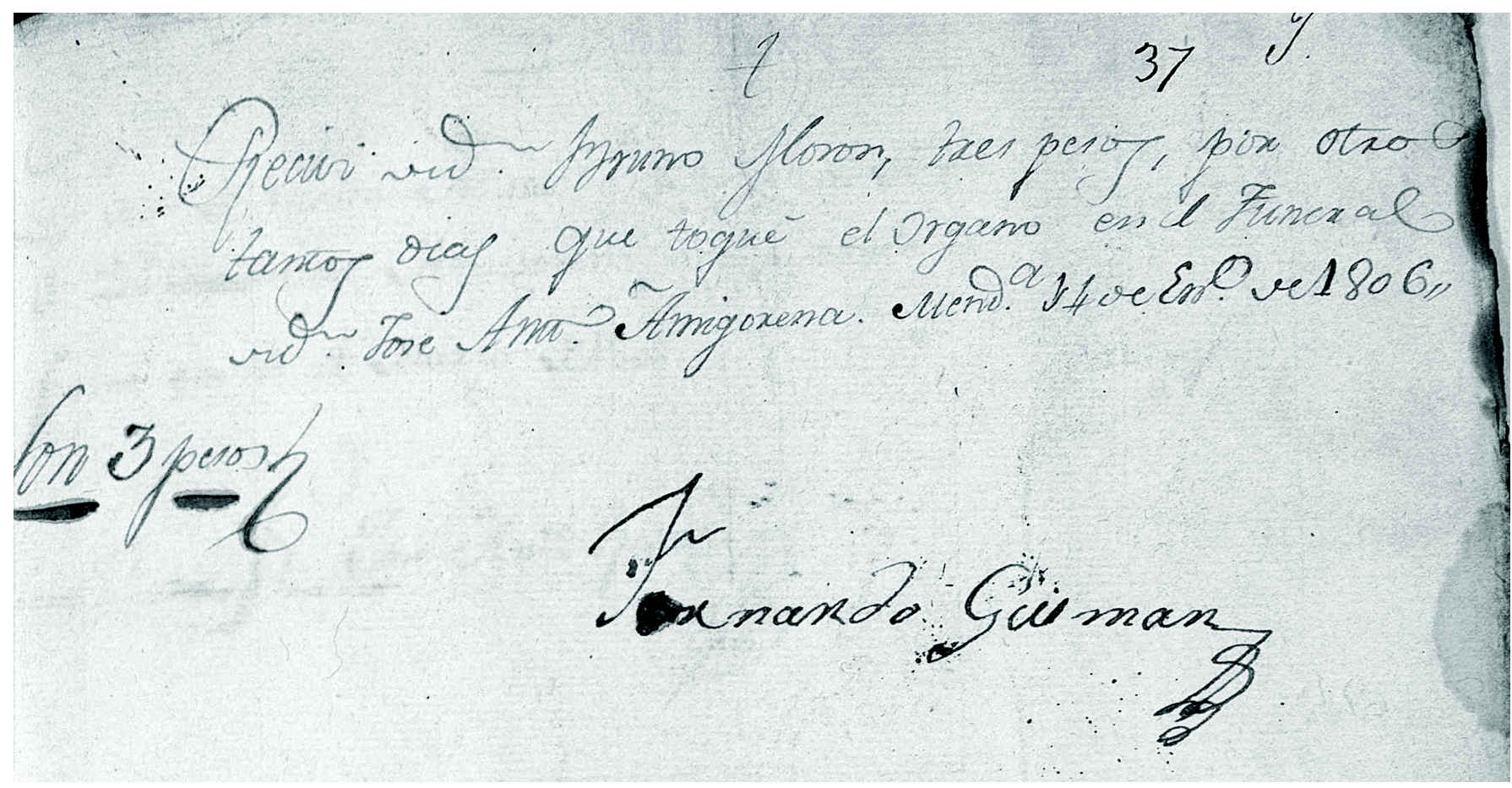

Figure 1. Fernando Guzmán invoice dated 14 January 1806.

The invoice reads:

"I received from Don Bruno Morón, three pesos, for as many days that I played the organ at the Funeral of Don José Antonio Amigorena. Mendoza, January 14, 1806, Fernando Guzmán."

Fernando was not only giving concerts at parties of the well to do families, playing the organ during Church ceremonies, but he was also organising and playing in public functions. According to Otero, ${ }^{3}$ in January 1814 Fernando performed in an event, as first violin of a sextet composed by six music teachers.

An invoice for that event was found and reported by Otero in his book. It indicates in detail, the number of musicians and the instruments played, as well as the number of musicians playing during day or night. At the function, given by the Mayor of Mendoza, the honoured guest was the Governor of the Province of Cuyo, General José de San Martin, who was soon to create a military force, an army of slaves or slave battalions, to fight for the independence of Argentina, Chile and Perú.

Regarding the function organised by the Mayor of Mendoza, Otero indicates about Fernando:

"In January 1814 we see him perform brilliantly in our city as the lead violin of an orchestra of six music teachers, on the occasion of an official party that lasted two days. In the Historical Archive of the Province there is an original document signed by Fernando Guzman, in which he presents the account of the expenses of said function."

On page 68 of his book Musica y musicos de Mendoza - Desde sus orígenes - hasta nuestro dias, Otero presents his version of the invoice dated 22 January 1814, as it appear in the documents found in the Historical Archive of the Province of Mendoza. It is an account of what the musicians earned in the functions of the Mayor, as invoiced by Fernando Guzmán, as the director of the group. Figure 2 below presents part of page 68 of Otero's book: 


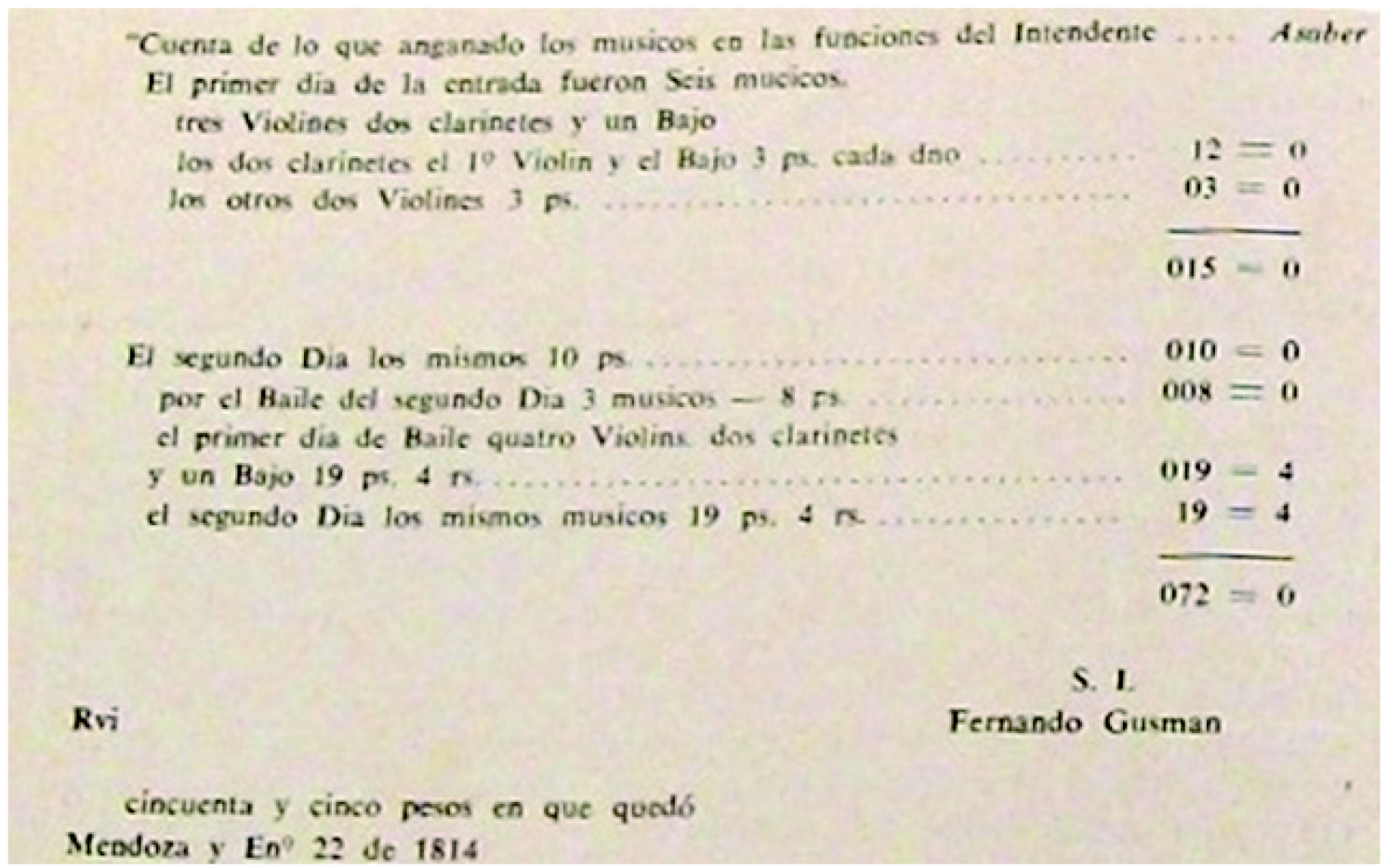

Figure 2. Part of page 68 of Otero's book.

Fernando married Juana Agustina, a slave belonging to the Molina Sotomayor family of Mendoza. Fernando made sure that all of their children, several of whom were also born into slavery like themselves, learned music and played musical instruments early in life. After their arrival in Chile, Fernando Guzmán was the first piano teacher to teach the different aspects of piano performance through scale exercises, revolutionizing the technique of teaching the instrument.

According to Zapiola Cortés, ${ }^{4}$ in his Recuerdos de treinta años, written in 1872, Fernando introduced a new method of teaching:

\begin{abstract}
"Don Fernando was the first teacher who had his disciples study scales and exercises before doing anything else. Previous teachers began from the first lesson with a minuet or a quadrille. We need not say what results this teaching could give."
\end{abstract}

Just like him, and perhaps because of the techniques employed by Fernando, all his children and several of his grandchildren, became accomplished musicians and musical teachers. Some of them became music academics and composers. He taught them well, using the techniques he learnt; to read and write music, and to practice using scale exercises.

But his true story and that of his children, was unknown. While the reason the story was never told is unknown, it is speculated that it was obfuscated due to the stigma in relation to slavery and their African heritage. But we owe it to him and his descendants that their story is told. To celebrate their life and work, we propose to discover and report how the family was composed and evolved.

\title{
Literature Review
}

In work published in the Cuadernos de Genealogía de Cuyo, Caballero ${ }^{5}$ relays his research about the Guzmán family, indicating that they were originally from Mendoza and settled in Chile in the 1820s:

"... the Guzmán ......., were from Mendoza who immigrated to Chile. They settled there from about 1820, and if there are descendants today, they would be on Chilean soil." 
The composition of the Guzmán family of classical musicians has been the subject of many reports, articles and comments, with many presenting errors and speculations. Some of these are due to the unavailability of source material of the époque.

In addition, there are other branches of the Guzmán family in Mendoza; Guzman's related to Fernando, such as his siblings and their descendants that remained in Argentina, when Fernando and his family made the journey to Chile.

Merino ${ }^{6}$ indicates that the literature, written by different authors and over a period of time, contains many errors and speculations about the composition, descent and/or ethnicity of some of the Guzmán's. Merino indicates:

"On this subject there are discrepancies in the bibliography of work published in Chile and Argentina in the last fifty years, both with regard to dates and composition of the family itself."

Merino ${ }^{7}$ further indicates that the errors have been shared in various publications and by various authors. These errors included how many children Fernando Guzmán had, the order of birth of the children, and also the paternity of others. For example, Morales Guiñazú ${ }^{8}$ and Morales Guiñazú, ${ }^{9}$ indicates that Dominga, Rosario and Paula were the daughters of Francisco Guzmán, their older brother, and not of Fernando Guzmán, their father. Some of these are physically impossible; Francisco was born in 1802 and Dominga was born in 1810.

According to Suarez, ${ }^{10}$ there were only seven children of Fernando Guzmán and that only six of them settled in Chile. Others, like Gasualdo ${ }^{11}$ and Otero, ${ }^{12}$ indicated that Fernando Guzmán had ten children. This investigation found yet another different number of children fathered by Fernando Guzmán. Merino ${ }^{13}$ further commented that Fernando's son, Francisco Guzmán and his wife Carmen Sánchez had seven children; again, a different number of children by the couple was identified by this investigation.

The origins of the Guzman's was never clear, other than they came from Mendoza. All articles and reports indicate that "they arrived in Chile from Mendoza in or about 1822", and no details about their parents, origins or ethnicity.

It has been confirmed that Fernando Guzmán was of African descent, with his mother being an African slave brought to Argentina. It is likely that his wife also came from similar ethnic origins, with her mother being an enslaved person of African ethnicity. The issue of slavery is mentioned by Caballero, ${ }^{14}$ who indicates that the Guzmán's were slaves and musicians:

"Their particularity: mulato slaves, and they were also musicians. This family was formed by the marriage of Fernando Guzmán, 21 years old, married to Juana Agustina Molina, 18 years old...."

It is mentioned in various articles and reports that Fernando Guzmán and his son Francisco, both accomplished pianists and violinists, arrived in Chile in 1822 (García Arancibia; ${ }^{15}$ Merino; ${ }^{16}$ Hernandez C; ${ }^{17}$ Otero; ${ }^{18}$ and Zapiola Cortés ${ }^{19}$ ); others indicate that it was $1823\left(\right.$ Pereira Salas ${ }^{20}$ ).

Zapiola Cortés, ${ }^{21}$ who knew the Guzman's and formed an orchestra with Fernando's sons Francisco and Eustaquio, indicates that Fernando and his son Francisco arrived from Mendoza in about 1822:

"The year 1822 was fruitful for music by happy coincidences. At the beginning of that year, or at the end of the previous one, Don Fernando Guzmán and his son Francisco had arrived from Mendoza, the first a piano teacher, and the second a good pianist and an outstanding violin."

It is possible that the Guzmán's move to Chile was motivated by the fact that Chile abolished slavery completely in 1823 . Argentina did not abolish slavery until much later, legally in 1853, which did not come into effect until 1860. Both countries had previously introduced the Freedom of the Womb (Libertad del Vientre) law, which made the birth of children of an enslaved mother, to be born free from slavery from the moment of birth; Chile introducing the law in $1811,{ }^{22}$ and on the 31 of January $1813^{23}$ Argentina introduced the new law.

\section{Investigation}

This research is carried out as a process of discovery, to establish, without any doubt, the relationships, number and ethnicity of the original Guzmán's and their numerous descendants, many of whom settled in Chile, after the country's independence from Spain.

María Juana, Fernando's mother, of unknown ethnic origin, though assumed African, was the matriarch of all the Guzmán's referred to in this research. This research is intended to review and investigate all possible information about the origin of the Guzmán family. 
Fernando Restituto, later Fernando Guzmán, became a pianist and violinist in Mendoza during the period of the late 1700s. It is also known that he married Juana Agustina; together they had many children. Their number, and occasionally the paternity of the children, is disputed in the literature published during the $20^{\text {th }}$ century. Most, if not all of the surviving children of Fernando Restituto and Juana Agustina, went on to become accomplished pianists, violinists, music teachers, as well as academics and composers. What was previously unknown is that both Fernando and his wife Juana Agustina were slaves of African descent.

The arrival in Santiago of Fernando and his 20-year old son, Francisco, the eldest and by then also an accomplished pianist and violinist, like Fernando, is reported in early 1820s. It is unknown if the rest of the family arrived at the same time or later. But it must have been before October 1824, since the youngest son of Fernando and Juana Agustina, also called Fernando, was born and baptized in Santiago in October 1824.

José Bernardo Suárez, ${ }^{24}$ a well known Chilean academic and writer that met Fernando Guzman and some of his children, wrote in 1872 in one of his works, his thoughts about Fernando Guzman and his performance as a pianist, alluding Fernando to Johann Sebastian Bach:

"Here is the Johann Bach of Spanish America, if not for the age and science of that eminent German musician and composer, at least for having given the Argentine Republic and Chile seven skilful musicians, without counting the grandchildren."

Information has also been found indicating that Fernando Restituto appears in a number of legal cases during the early parts of the $19^{\text {th }}$ century.

One of these legal cases is related to the purchase of his own son, Francisco. On 24 December $1802,{ }^{25}$ Fernando legally bought his son from the infant's owner, Francisco Xavier Molina, who was the Mayor of Mendoza at the time, and the owner and master of his wife, Juana Agustina.

Legal documents were found that indicates that in 1806, Fernando played the organ at the vigil and funeral of José Antonio Amigorena.

Another legal case that is mentioned in literature is that Fernando Restituto took the Dominican Convent of Mendoza and its clergy to the Spanish Royal Court, since the clergy refused to grant him freedom from slavery. The priest who denied him his freedom was Fray Matías del Castillo, Governor of the Santo Domingo Convent of Mendoza, between 1809 and 1815 . According to Mallo, ${ }^{26}$ Fernando Restituto took the Dominicans to the Royal Court, but lost his case when the Court indicated:

"Justice, however, it has not yet been pronounced and freedom has been agreed out of court."

Documents were also found and it is mentioned also in published material that Fernando Restituto was an Oficial Pardo, ${ }^{27}$ as mentioned in the baptismal documents of his son Victor Cesareo, dated 27 November 1817. He enrolled and formed part of the army of slaves or slave battalions, a militia group created by General San Martin, in preparation for war with Spanish forces in Argentina, Chile, and Perú. San Martin promised freedom from slavery, after the end of the war, to all the slaves who enlisted (and remained enlisted); about four thousand slaves joined the ranks of his army.

The Guzmán's ethnicity has been confirmed by Autosomal DNA tests by two individuals from families related to two sons of María Juana, the matriarch of the original Guzmán from Mendoza. The two individuals, one a descendant of Juan Bernardino, the eldest of the sons of María Juana, and the other a descendant of Fernando Restituto, underwent Autosomal DNA testing without knowing each other, and after having exchanged correspondence about their links to the Guzmán family. The Autosomal DNA test results indicated that the two individuals are related, and both presented a certain level of African ethnicity; they are $5^{\text {th }}$ cousins once removed.

One of the individuals presented a lower degree of African ethnicity; this was because his relative of Guzmán origin married a person of nonAfrican descend; and in the case of the other individual, his relative of Guzmán origin, married an Afro-descendant person, who had also been born enslaved in Mendoza.

It has been confirmed that Fernando Restituto and his wife Juana Agustina were slaves; Fernando a slave of the Dominican Convent; Juana Agustina a slave of Francisco Xavier Molina. Upon the death of Francisco Xavier Molina in 1805, Juana Agustina and some of the couple's children became slaves of Molina's widow, Josefa Sotomayor, who inherited all his possessions, including all the slaves. 
Research Method and Terminologies

The research made use of many of the Mendoza Parish Books from the $18^{\text {th }}$ and $19^{\text {th }}$ century, books created and maintained by the Parishes of the Catholic Church and audited on a regular basis by the Church authorities. The books were kept to record all Baptisms, Marriages and Deaths of the faithful in the nascent colonies.

The books provided an excellent source of material for this investigation and most of them have been photographed, with material extracted digitised and converted into databases by and are available at FamilyResearch.org. Not all the records of the period are available, with cases of book pages which have been damaged and could not be extracted or photographed. At times, some books were missing altogether.

The databases proved especially useful when details - such as name and birth year - of the individual been sought, were known. Otherwise, the records were searched in a sequential manner checking each digitised entry of the books manually, page by page. The searching of the photographed individual images was a lengthy and time consuming process. Figure 3 below is an example of a series of images of the Mendoza Baptism Book shown entries for August - September 1812:28

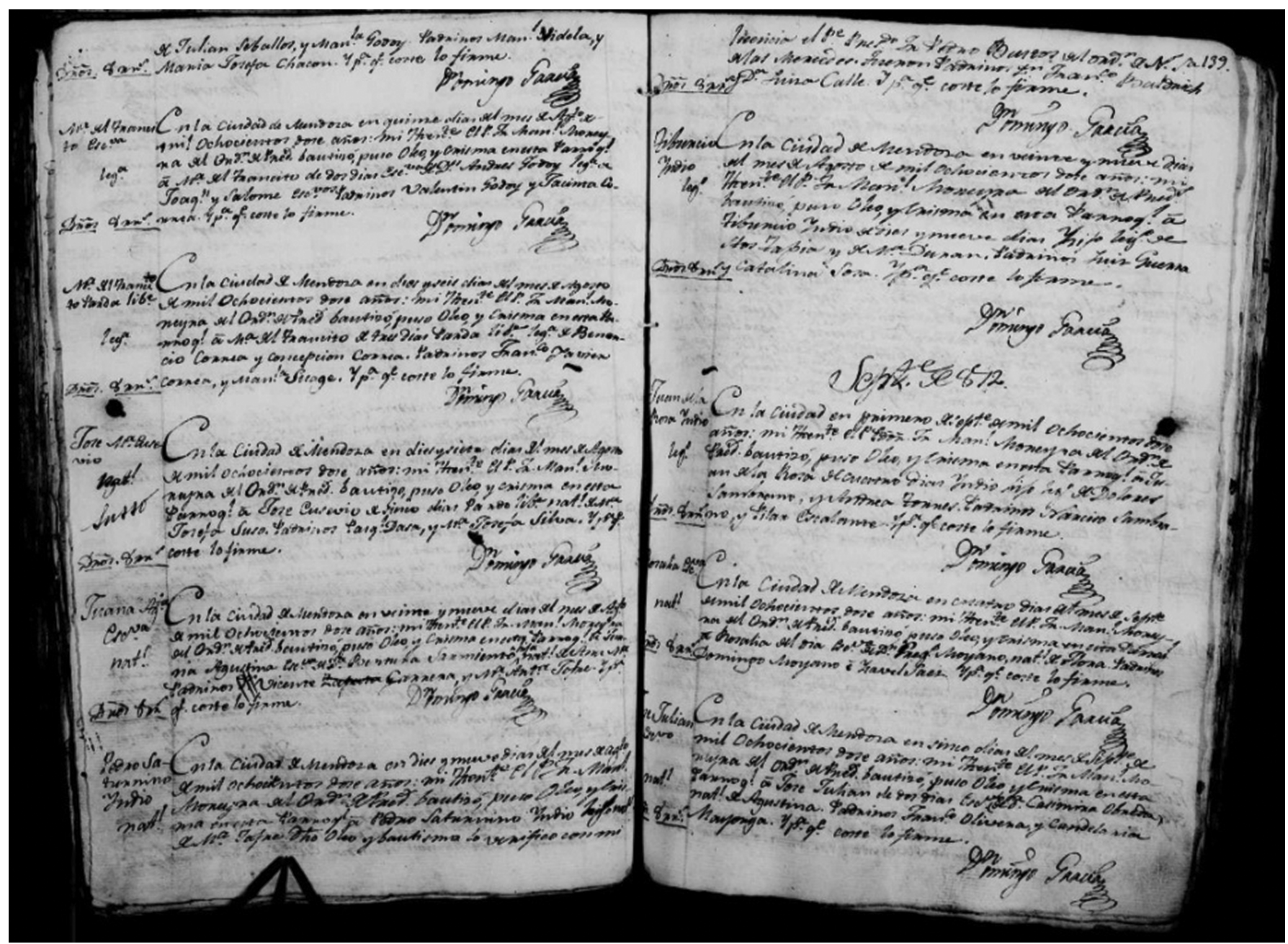

Figure 3. Mendoza Baptism Book August - September 1812.

The books present other challenges, like the terminology used in them. For example, during South America's Spanish colonial period, a society was established that recognised, and was based on, three classes of people: white people, who were Spanish or otherwise European; Indian or indigenous people, the native people; and Black people, who were slaves, brought in from African countries. 
The Church documents of the time reflect these classifications and they kept separate set of books for the Indigenous or Indigenousdescended and African or African-descended population, and the Spanish population. Different sets of books were kept for the three different types of entries made by the Church, that is, to record baptisms, marriages and deaths. The front page one of the Mendoza Baptisms Book, the one covering the baptisms from 1759 to 1774 , from which some of the documentation presented were obtained from, reads:

"Book of Baptisms of Indians, Mulattoes and Blacks Made by Mr. Doctor Don Francisco Correa de Saa, Rector and Vicar Priest, Elected Judge and Tithes Commissioner of the Holy Cross of this city of Mendoza, Honorary Vicar and elected Judge of this Province of Cuyo, Mendoza and October 29, 1759 ...to $1774 . "$

There were a number of classifications encountered during the research when using the Church sets of books. These classifications were: Español, Indian, Mestizo, Negro, Mulato, Pardo, Libre or Liberto, Cuarteron, Zambo, Cholo and Chino. The classifications have been established as having the meanings presented in the following table. Table 1 - Church Books Classifications and Descriptions below present the classifications and descriptions encountered in Church books:

Table 1. Church Books Classifications and Descriptions.

\begin{tabular}{|c|c|}
\hline Classification & Description \\
\hline Español/a & refer to people of white European heritage \\
\hline Indio/a & an indigenous person or of indigenous descent \\
\hline Mestizo/a & $\begin{array}{l}\text { a person of mixed race, especially one from Español and Indian descent, a person with one Español and } \\
\text { one Indian parent }\end{array}$ \\
\hline Negro/a & people of African origin who were considered slaves and were bought and sold \\
\hline Mulato/a & $\begin{array}{l}\text { a person of mixed Español and Negro ancestry, especially a person with one Español and one Negro } \\
\text { parent. Many of them were slaves if their mother was a slave, and were also bought and sold }\end{array}$ \\
\hline Pardo/a & $\begin{array}{l}\text { a person of mixed Español, Negro and Indian ancestry. Many of them were slaves if their mother was a } \\
\text { slave, and were also bought and sold }\end{array}$ \\
\hline Libre or liberto/a & a person formerly enslaved who was released from slavery, usually by legal means \\
\hline Cuarterón/a & $\begin{array}{l}\text { a person of mixed race, being of Español and Mestizo descent, especially a person with one Español } \\
\text { and one Mestizo parent }\end{array}$ \\
\hline Zambo/a & $\begin{array}{l}\text { a person of mixed Negro and Indian ancestry, especially a person with one Negro and one Indian } \\
\text { parent }\end{array}$ \\
\hline Cholo/a & $\begin{array}{l}\text { a person of mixed Mestizo and Indian ancestry, especially a person with one Mestizo and one Indian } \\
\text { parent }\end{array}$ \\
\hline Chino/a & $\begin{array}{l}\text { a person of mixed Indian and Mulatto ancestry, especially a person with one Indian and one Mulatto } \\
\text { parent }\end{array}$ \\
\hline
\end{tabular}

Use is also made of the 1802 and 1814 Parish census of the inhabitants of the Curate of the City of Mendoza. Other material used was from available literature, newspapers, and from legal documents found during the research process.

Research

\section{From Africa to South America}

Towards the end of the $16^{\text {th }}$ century and during the $17^{\text {th }}$ century, the first Africans slaves arrived in Argentina. Some came from Southern Equatorial Africa, Angola, Congo and Mozambique, and others from Southeast Africa. Between 1777 and 1812, more than 700 ships entered the port of Buenos Aires in Argentina, and Montevideo in Uruguay, with 72,000 African slaves. ${ }^{29}$ 
Many slaves recently arrived in Argentina from Africa and on their way to Perú via Valparaíso to be sold, if/when the passes were closed due to bad weather over the Andes Mountain, they then had to make a stopover in Mendoza. While in Mendoza, some of the enslaved people were acquired by the wealthiest in the small community of Mendoza, or by the different convents, Dominicans, Augustinians, Jesuits, or Mercenaries.

It has been established that María Juana, Fernando Restituto's mother, was a slave belonging to the Santo Domingo Convent in Mendoza. No documentation has been found of María Juana, of her arrival in Mendoza, of her birth or of her baptism there. DNA ethnicity results from direct descendants indicate Nigerian and Algerian origins.

In addition, no information has been found indicating the father(s) of María Juana several children. All her children, whose baptism, marriage or death documents have been found, indicate they were "mulato or mulata slave of unknown father". Using the description given of the classification of mulato or mulata under Table 1, which indicates an individual with one Español and one Negro parent, it can be assumed that María Juana children's father(s) were Spanish or of Spanish descent. A direct descendant, trying to discover the male ancestry, had a Y-DNA test; it provided little or no information, with no 111 Markers matches, and only 267 Markers matches, found.

It is noted that all slaves belonging to the Dominican Convent, as part of the ownership naming process, were given the surname of Guzmán, the surname of the founder of the Dominican Order, Santo Domingo Félix de Guzmán (1170-1221). Juana Agustina, Fernando's wife, carried the surname of Molina, as she was owned by a person of that name.

This investigation will cover Fernando Restituto, as Fernando Guzmán appears in documentation of the $18^{\text {th }}$ century, his wife, Juana Agustina Molina, and their direct descendants.

\section{Fernando Restituto}

Fernando Restituto was born in Mendoza 6 June 1778, the son of María Juana and an unknown father. He was baptized 6 December $1778^{30}$ in the Parish Church. His baptism record appears on two pages of the record book, at the bottom of page of folio 129 and at the top of page of folio 130. The Folios indicate that Fernando Restituto was five months old, a mulato natural son of María Juana, a slave of the Santo Domingo Convent, and of an unknown father. Figure 4 shows Folio 129 and Figure 5 Folio 130 of 6 December 1778:

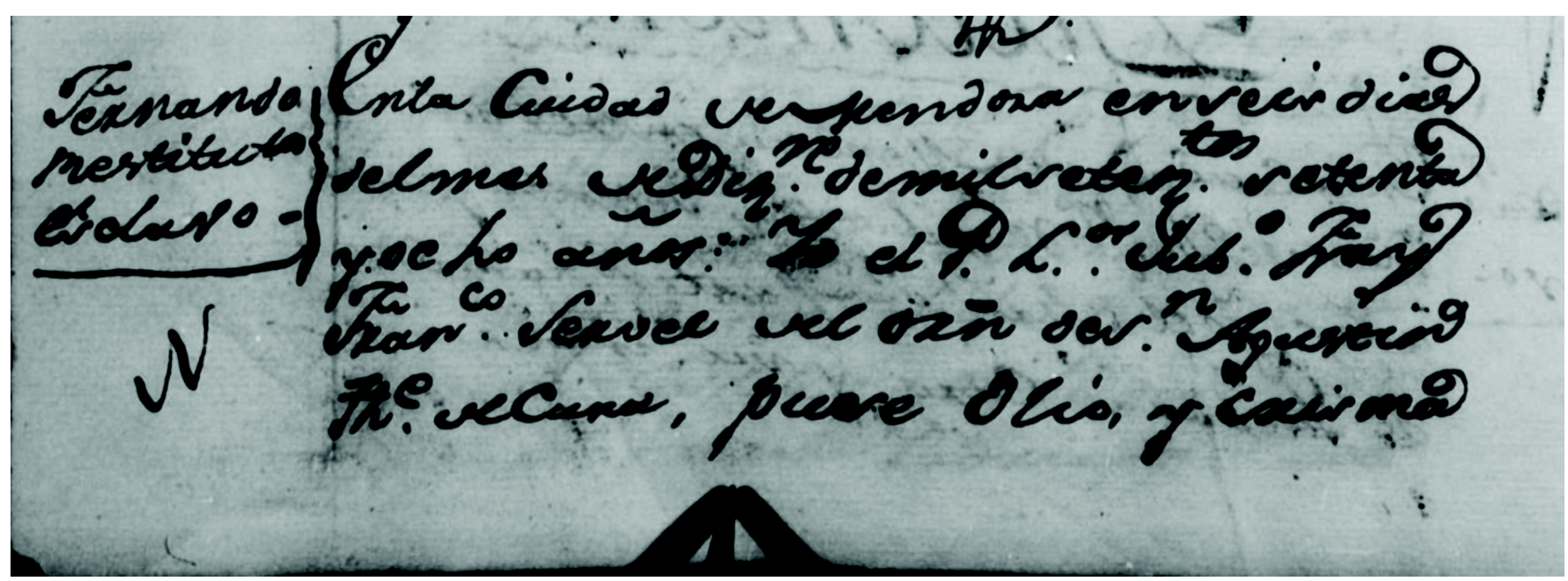

Figure 4. Folio 129 of 6 December 1778. 


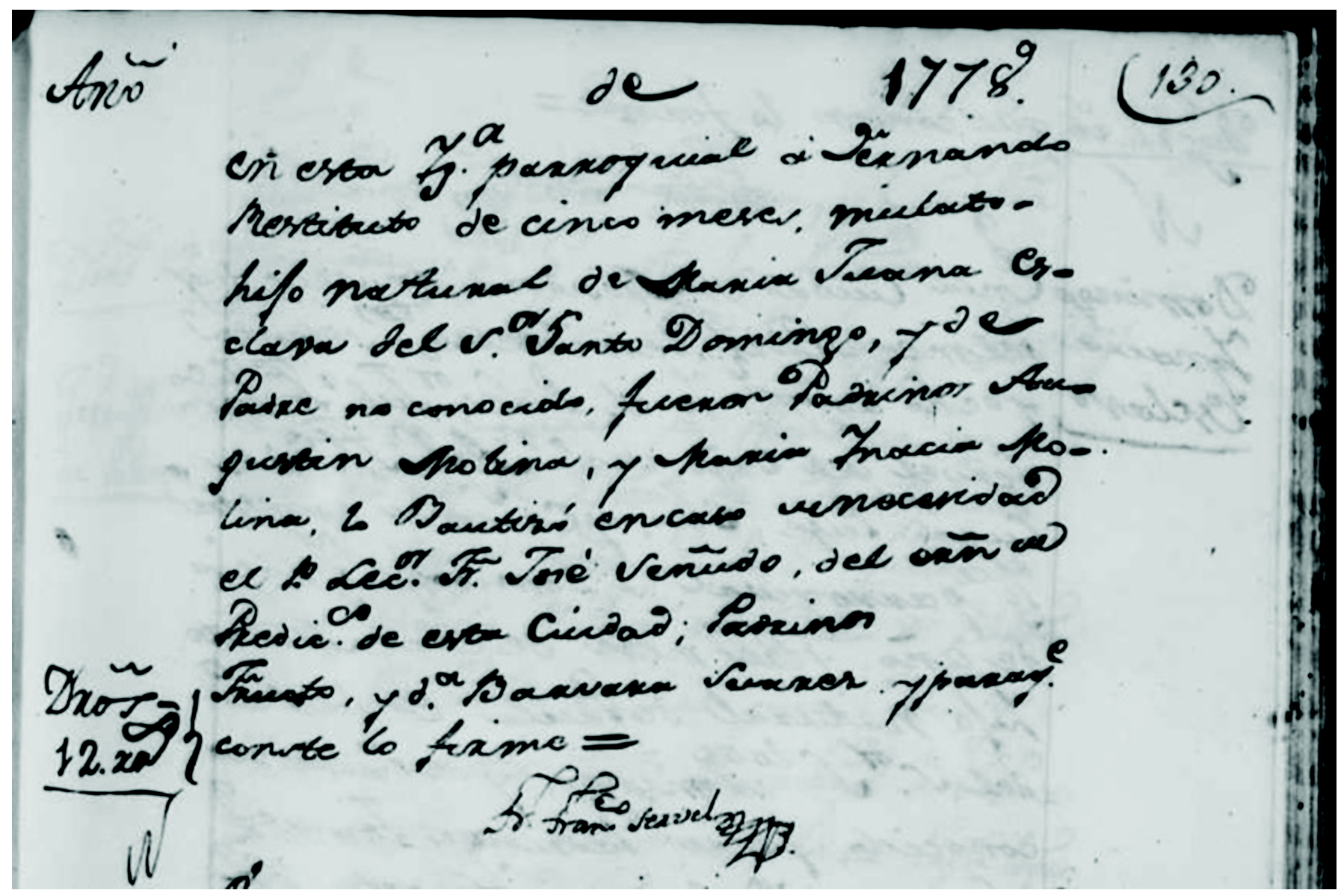

Figure 5. Folio 130 of 6 December 1778.

The document indicates that Fernando Restituto was baptized in case of need (meaning that he was in danger of death).

Fernando Restituto married Juana Agustina in Mendoza in 1799. It was unknown until recently, that Juana Agustina was also a slave and of African descent. Juana Agustina was a slave belonging to Francisco Xavier Molina. Fernando and Juana Agustina had 13 children. Several of their children were also born in slavery like their parents, but not slaves of the Dominican Convent, but rather of the master and mistress of Juana Agustina, the Molina Sotomayor family. From this time onwards, Fernando will appear in documentation as Fernando Guzmán, as no further mention of Fernando Restituto is recorded in the literature.

Fernando was 21 years old, and Juana Agustina 18 years old when they married. Juana Agustina's documentation is presented that confirms her maternity and social status; her owners will become the owners of several of the couple's children.

\section{Juana Agustina}

Juana Agustina was born in Mendoza 23 June 1781, daughter of Francisca Borja and an unknown father. Juana Agustina was baptized 24 June $1781^{31}$ in the Parish Church. Her baptism record on Folio 214 of the registry book indicates that Juana Agustina was one day old, was a mulata slave of Ventura Videla, a natural daughter of Borja. Figure 6 shows Folio 214 of 23 June 1781: 


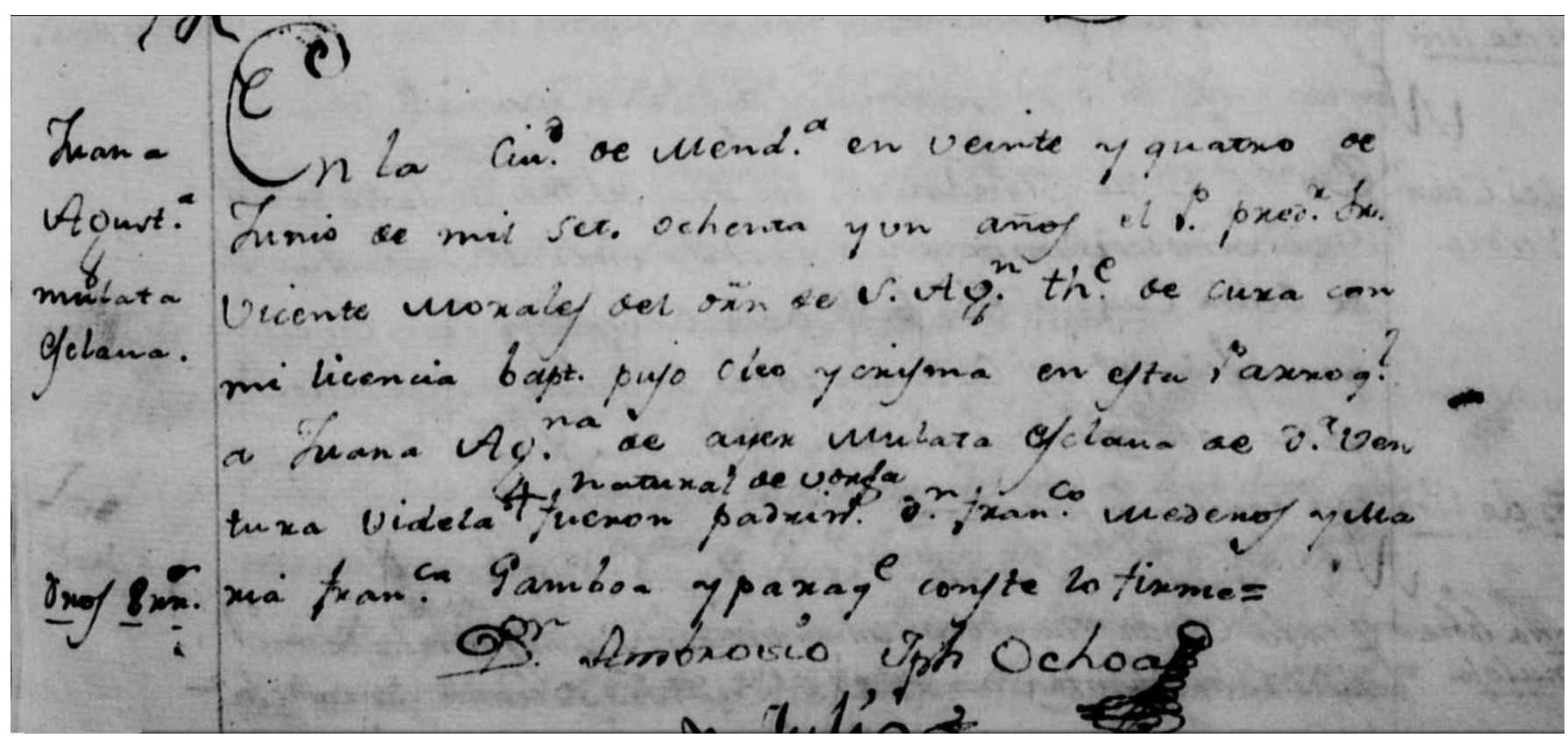

Figure 6. Folio 214 of 23 June 1781.

Borja and Juana Agustina were slaves of Ventura Videla, Francisco Xavier Molina's mother; it is assumed that Francisco Xavier Molina inherited some of his parent's slaves when they died. It is also noted that Juana Agustina had six younger siblings, children of the marriage of her mother Borja and Pedro, also a slave of Francisco Xavier Molina.

\section{Fernando Guzmán and Juana Agustina Molina}

The marriage of Fernando and Juana Agustina was registered in Folio 236 of the Marriage Register of 24 June $1799,{ }^{32}$ and indicates that Fernando Guzmán was a mulato slave of the Santo Domingo Convent, that he was the natural son of María Juana, a slave of the Convent, and was marring Juana Agustina, a mulata slave of (Francisco) Xavier Molina, natural of Mendoza, and a natural daughter of Francisca Borja, a slave of the same (Francisco) Xavier Molina; the Witnesses were Jorge Corvalán and Magdalena Godoy. Figure 7 shows Folio 236 of 24 June 1799 : 


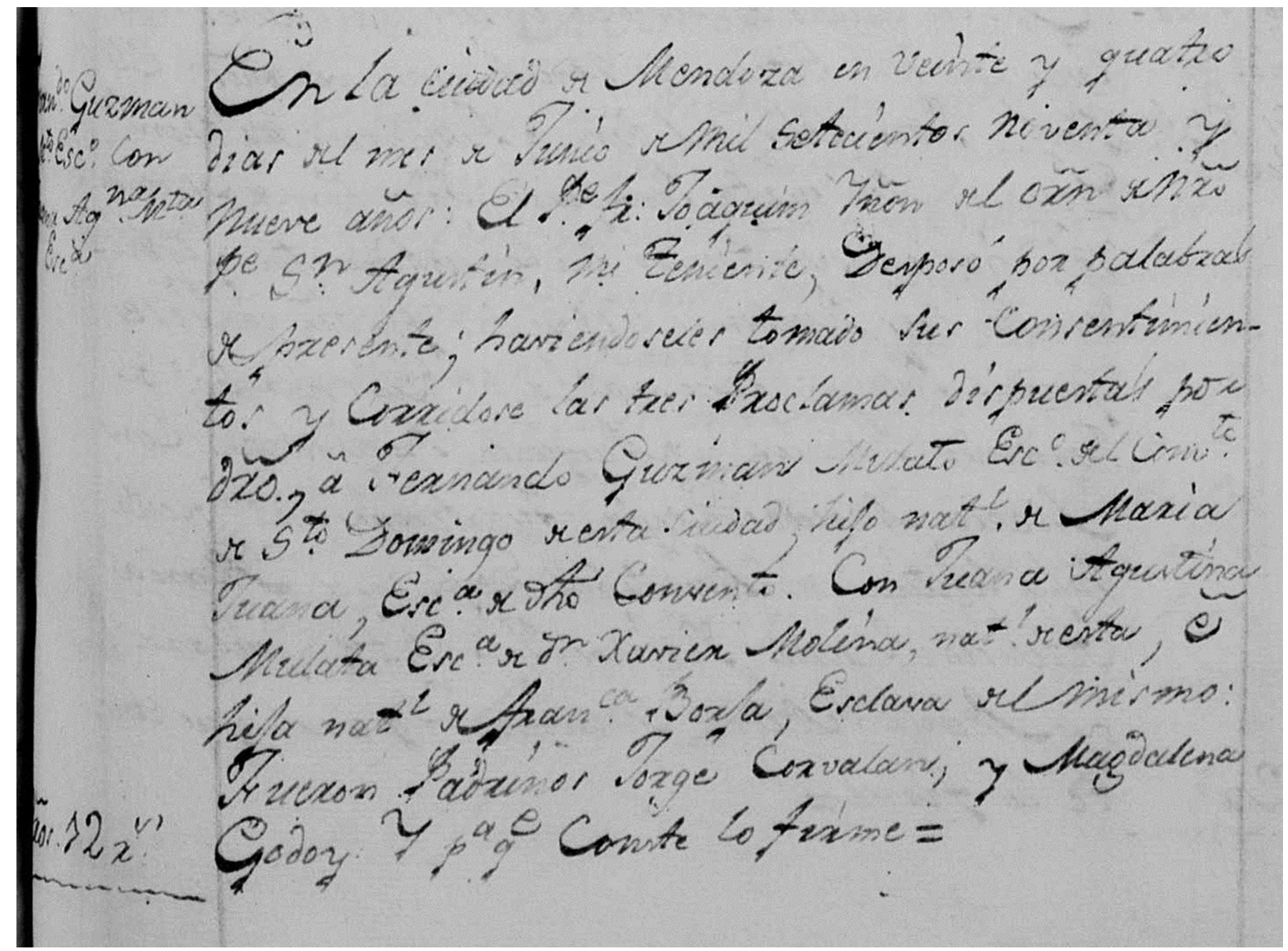

Figure 7. Folio 236 of 24 June 1799.

\section{The Guzman Molina Family}

Fernando and Juana Agustina were the parents of thirteen children. Twelve of them were born in Mendoza; the first six were born into slavery, being owned by the Molina Sotomayor family. As Juana Agustina was a slave of Francisco Xavier Molina, their children were also slaves of Francisco Xavier Molina; upon his death in 1805, they became slaves of his widow, Josefa Sotomayor. The next six children were born in freedom. The youngest, Fernando junior, was born after their arrival in Chile.

Fernando and Juana Agustina children, in order of birth, were: Justa del Carmen, Francisco, Bernardina, Genaro Eustaquio, María Gertrudes, Dominga Damiana del Rosario, Encarnación, Eustaquio, Paula, Víctor Cesareo, María del Carmen, María del Rosario y Fernando. Figure 8 presents the direct descendants of Fernando and Juana Agustina who have been identified and for which documented evidence exist and are included as part of the report. 


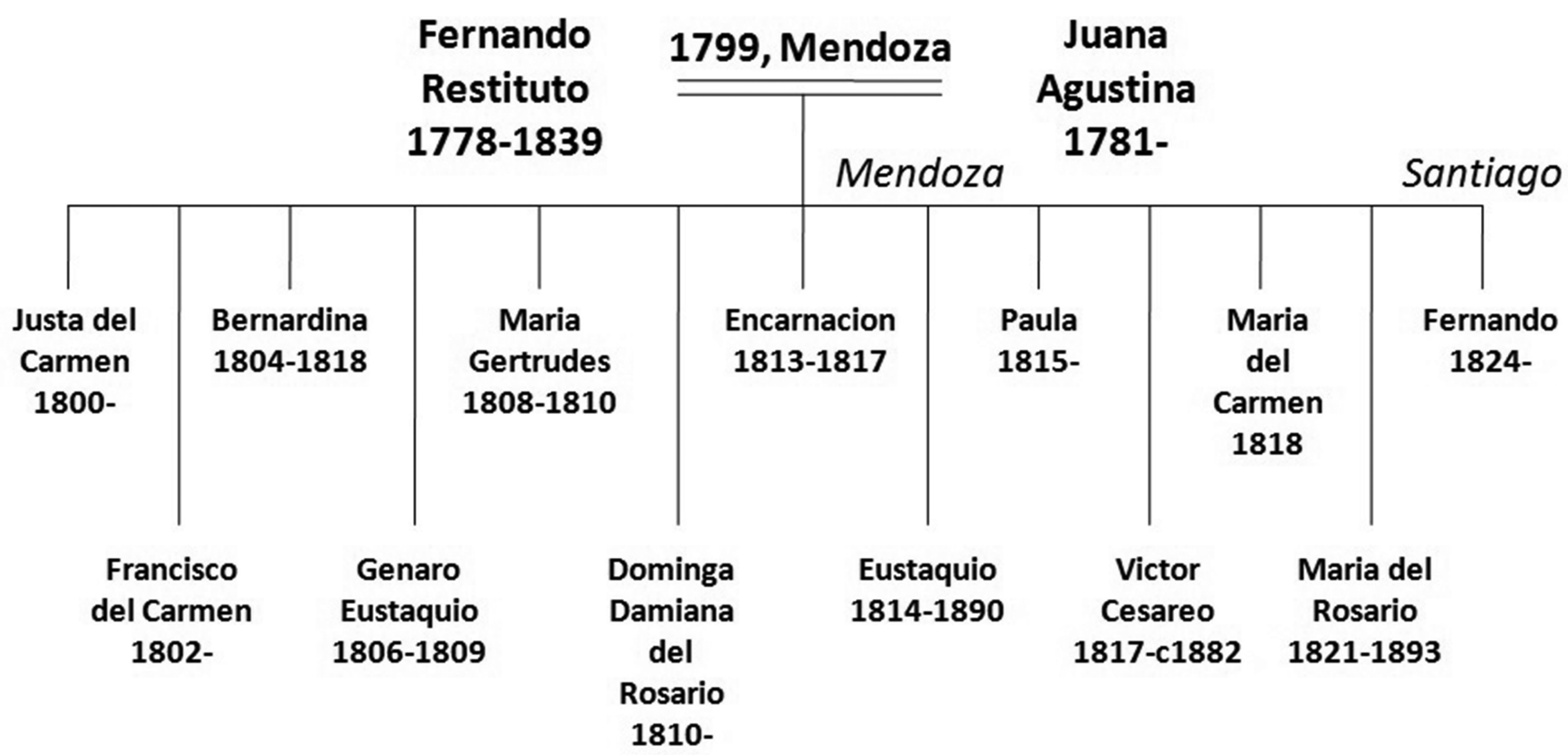

Figure 8. Direct descendants of Fernando and Juana Agustina.

\section{Justa del Carmen}

Justa del Carmen was born in Mendoza 27 May 1800. The documents of her baptism, dated 30 May 1800, ${ }^{33}$ indicate that Justa del Carmen was three days old, a Mulata Slave of (Francisco) Xavier Molina, and a legitimate daughter of Fernando Guzmán and Juana Molina; that the godparents were Jorge Corvalán and María Magdalena Godoy. Figure 9 shows Folio 34 of 30 May 1800:

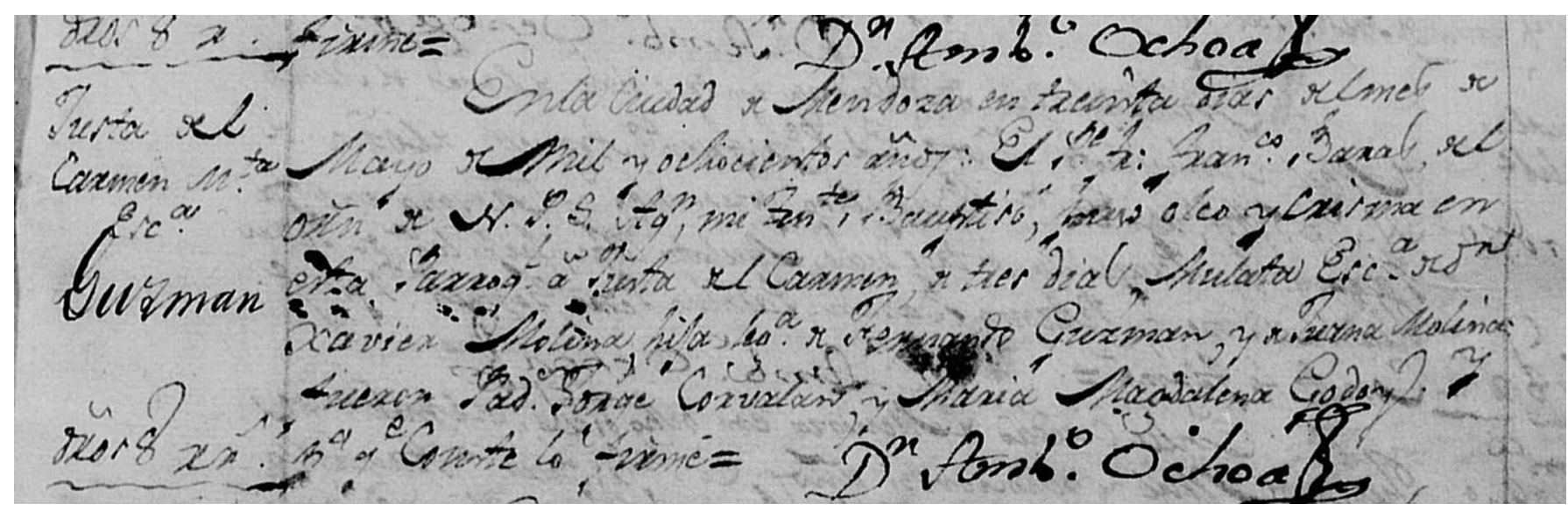

Figure 9. Folio 34 of 30 May 1800.

The only other document that Justa del Carmen appears in is in the 1802 Parish Census. ${ }^{34}$ The 1802 Parish census of the inhabitants of the Curate of the City of Mendoza, started on 1 April 1802, carried out by Mr. Domingo García, by order of the Most Illustrious Bishop of Santiago de Chile Mr. Francisco José de Maran. Justa del Carmen is listed in the Census and appears as a two years old. The Census entry reads: "Justa, slave, two years". Justa del Carmen does not appear on the next Census, the 1814 Parish Census. No additional information was found about Justa del Carmen. 


\section{Francisco del Carmen}

Francisco was born in Mendoza in July 1802. The documents of his baptism are dated 15 July $1802,^{35}$ indicating that Francisco del Carmen was a mulato slave of (Francisco) Xavier Molina, a legitimate son of Fernando Guzmán and Juana Agustina Molina. Godparents were Francisco Medinos and María del Carmen Morales. The document also indicates that Francisco became free at the moment of the baptism. Figures 10 and 11 shows Folios 54 and 55 of 15 July 1802:

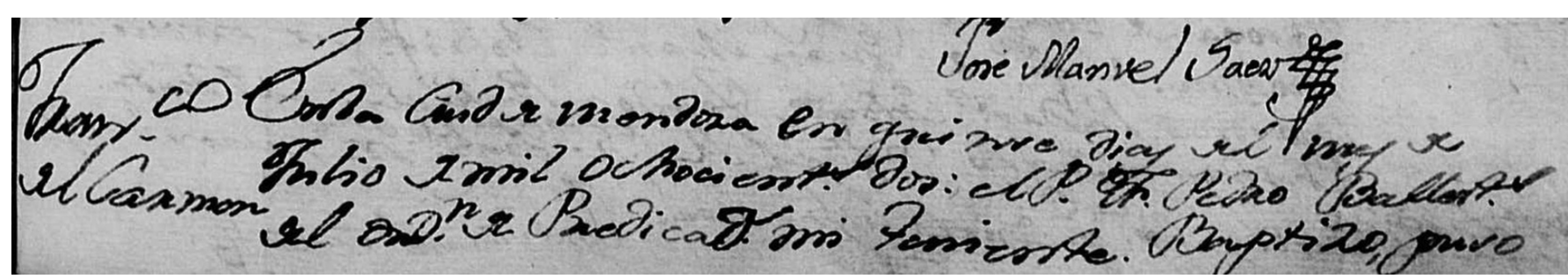

Figure 10. Folio 54 of 15 July 1802.



Figure 11. Folio 55 of 15 July 1802.

It is noted that the comment regarding Francisco's freedom seems to have been written after the Christening, since the handwriting and the ink used in the document, are different from the christening entry itself. The event of his freedom happened about 6 months after the christening, and not by the process of putting oils upon him as it is indicated.

The statement about Francisco's freedom was proven true, by legal documents that indicate that Fernando bought his freedom. On 24 December $1802{ }^{36}$ Fernando succeeded in buying his son from the child's owner, Francisco Xavier Molina, the owner and master of his wife, Juana Agustina.

Francisco went on to become a pianist and violinist. It is mentioned in various reports and articles that Fernando Guzmán and his son Francisco, both accomplished pianists and violinists, arrived in Chile between 1822 and 1823.

Merino $^{37}$ recount the story mentioned by Zapiola Cortés about the first lyrical company to tour Chile in 1830, saying:

"Zapiola evokes that when arriving in el winter 1830 "the first lyrical company that has come to Chile", the orchestra under his direction had "Francisco Guzmán as main violin and as first cello his brother Don Eustaquio."

Neuma ${ }^{38}$ indicates that Francisco specialised in orchestral music, indicating of Francisco:

"He was pre-eminently an orchestral musician and performed few solo activities."

Hernandez $\mathrm{C}^{39}$ indicates that Francisco was a good pianist and an outstanding violinist: 
"During those years had come from Mendoza don Fernando Guzmán and his son Francisco, teacher, the first, of piano; and the second good pianist and outstanding violinist."

Francisco Guzmán married Carmen Sánchez in Chile and they were the parents of ten children. He later became an academic at the National Conservatory of Music.

\section{Bernardina}

Bernardina was born in Mendoza 19 May 1804. The documents of her baptism dated 20 May $1804^{40}$ indicate that Bernardina was a day old, a legitimate daughter of Fernando Guzmán and Juana Molina, and a mulata slave of (Francisco) Xavier Molina. Godparents were Feliciano Molina and Dolores Molina. Figure 12 shows Folio 103 of 20 May 1804:

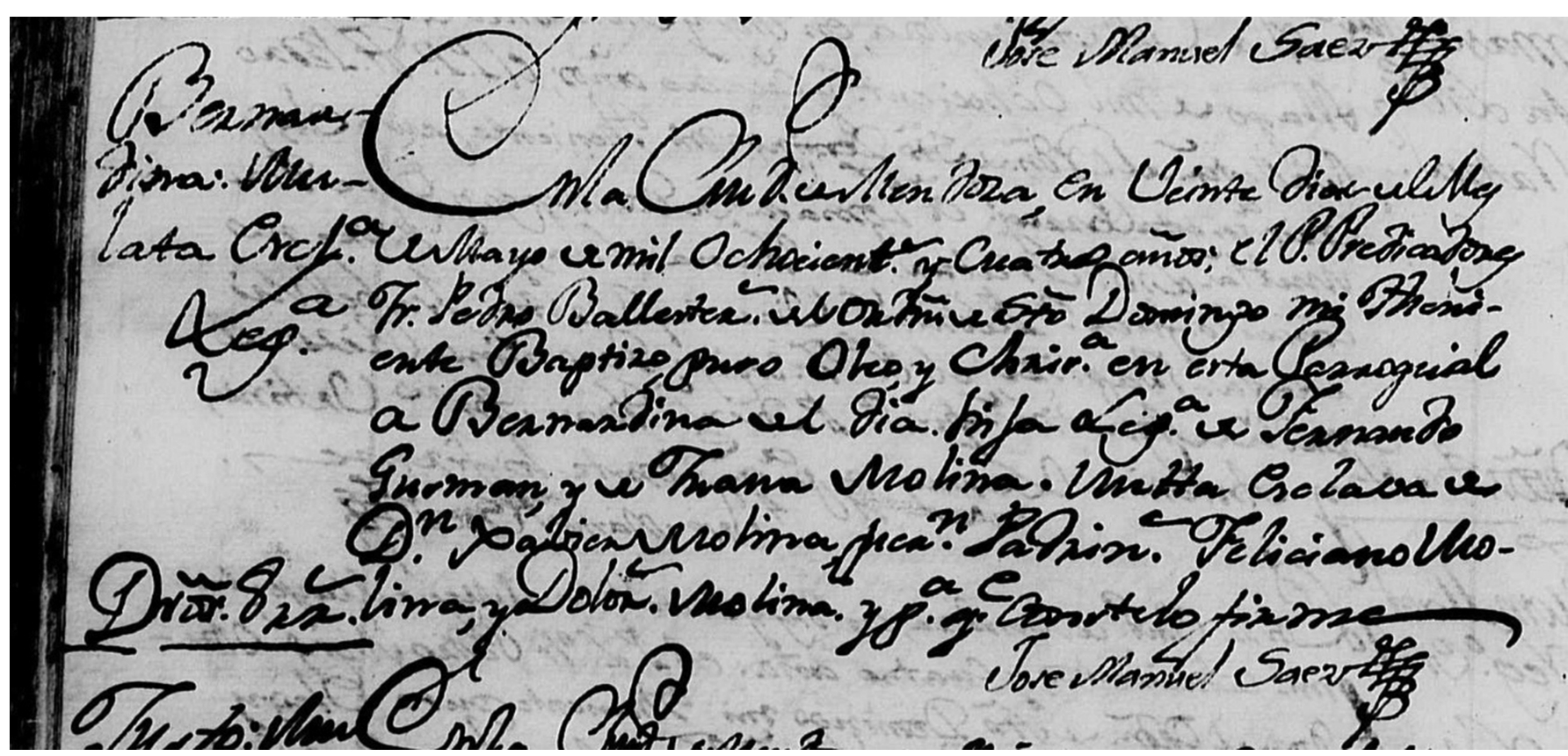

Figure 12. Folio 103 of 20 May 1804.

Bernardina died in Mendoza 9 October $1818 .^{41}$ The death documents indicate that Bernardina Molina died in Mendoza age 13, estimating that she had been born in 1805. It should be noted that her parents are not identified in the documents, a common practice at the time. The Folio dated 9 October 1818 indicates her name as Bernardina Molina, was a thirteen-year-old mulata slave of Josefa Sotomayor. Figure 13 shows Folio 62 of 9 October 1818:

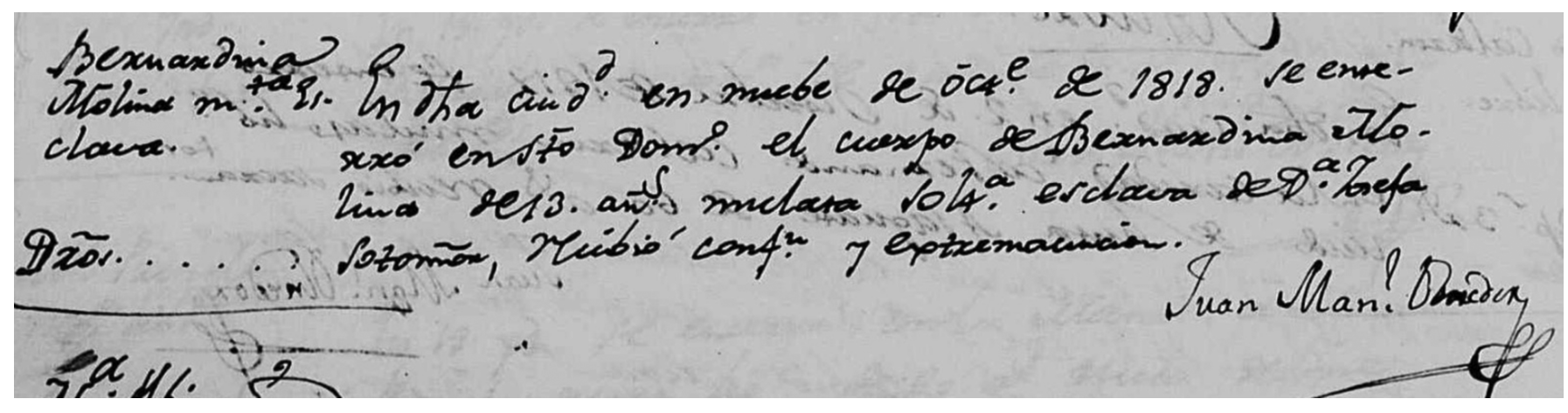

Figure 13. Folio 62 of 9 October 1818. 


\section{Genaro Eustaquio}

Genaro Eustaquio was born in Mendoza 19 September 1806. The document of his baptism, dated 20 September 1806, ${ }^{42}$ indicates that Genaro Eustaquio was one day old, a mulato slave of Josefa Soto-Mayor, and a legitimate son of Fernando Guzmán and Juana Soto-Mayor. Godparents were Enrique Acosta and Francisca Núñez. Figure 14 shows Folio 192 of 20 September 1806:

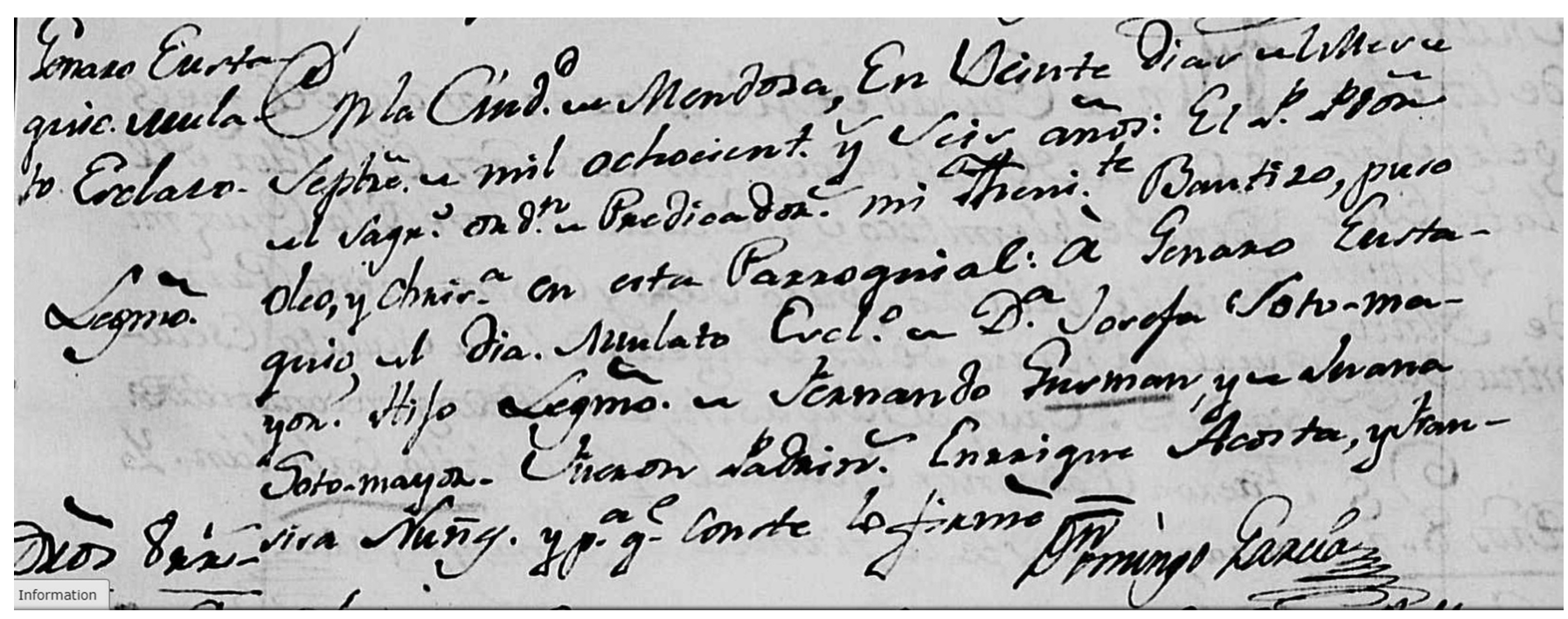

Figure 14. Folio 192 of 20 September 1806.

Genaro Eustaquio and his mother Juana Agustina appear as slaves of Josefa Sotomayor. In addition, the surname of Juana Agustina changed from Molina to Sotomayor (or Soto-Mayor). This is because Francisco Xavier Molina died 1 July 1805; his widow, Josefa Sotomayor, inherited all the slaves.

Genaro Eustaquio died in Mendoza 15 December $1809^{43}$ age 3 years and 3 months old. It should be noted that his name appears without a surname and his parents are not identified in the documents, indicating his name as Eustaquio, an infant slave. Figure 15 shows Folio 190 of 15 December 1809:

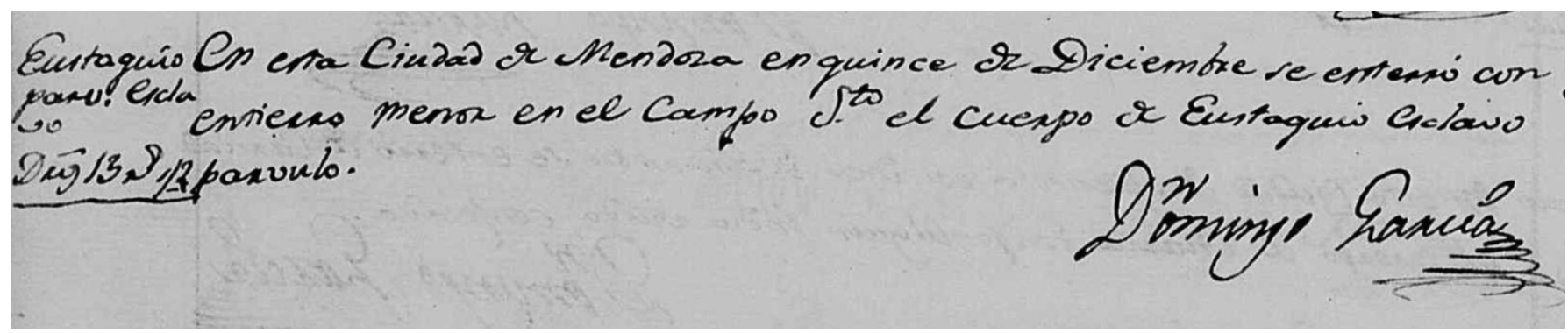

Figure 15. Folio 190 of 15 December 1809.

\section{María Gertrudes}

María Gertrudes was born in Mendoza 15 November 1808. The documents of her baptism dated 17 November $1808^{44}$ indicate that María Gertrudes was two days old, a parda slave of Josefa Sotomayor, and a legitimate daughter of Fernando Guzmán and Juana Agustina Molina. Godparents were Juan Pablo Ortiz and Jacova Lara. Figure 16 shows Folio 39 of 17 November 1808: 


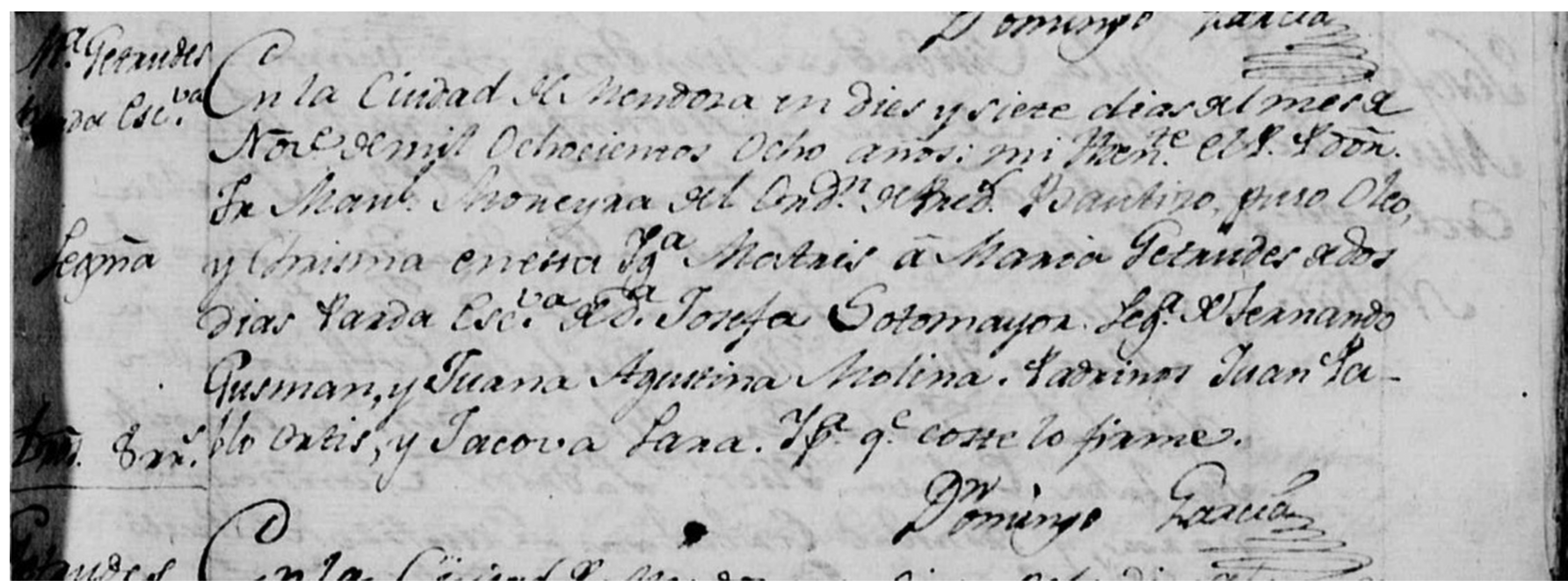

Figure 16. Folio 39 of 17 November 1808.

Gertrudes died in Mendoza 14 August $1810^{45}$ at age of 1 year and 9 months old. It is noted that her surname appears as Sotomayor, the surname of her owner, Josefa Sotomayor widow of Molina, and her parents are also not identified in the documents. The entry in Folio 194 indicates her name as Getrudes Sotomayor, and that she was a toddler and a slave. The spelling mistake and the different surname, made the identification of Gertrudes documents, difficult. Figure 17 shows Folio 194 of 14 August 1810:

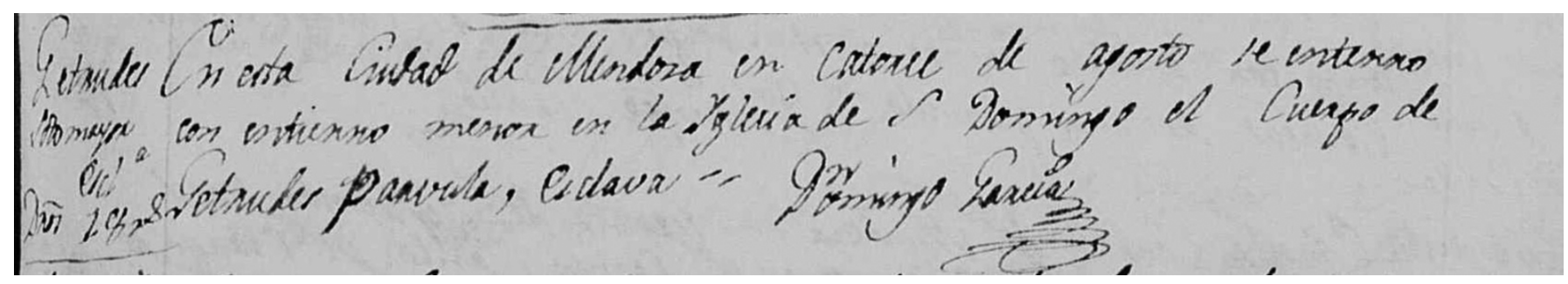

Figure 17. Folio 194 of 14 August 1810.

\section{Dominga Damiana del Rosario}

Dominga was born in Mendoza 26 September 1810. The documents of her baptism dated 28 September $1810^{46}$ indicate that Dominga Damiana del Rosario was two days old, a mulata slave of Josefa Sotomayor, and a legitimate daughter of Fernando Guzmán and Juana Molina. Godparents were Enrique Acosta and Francisca Núñez. Figure 18 shows Folio 89 of 28 September 1810: 


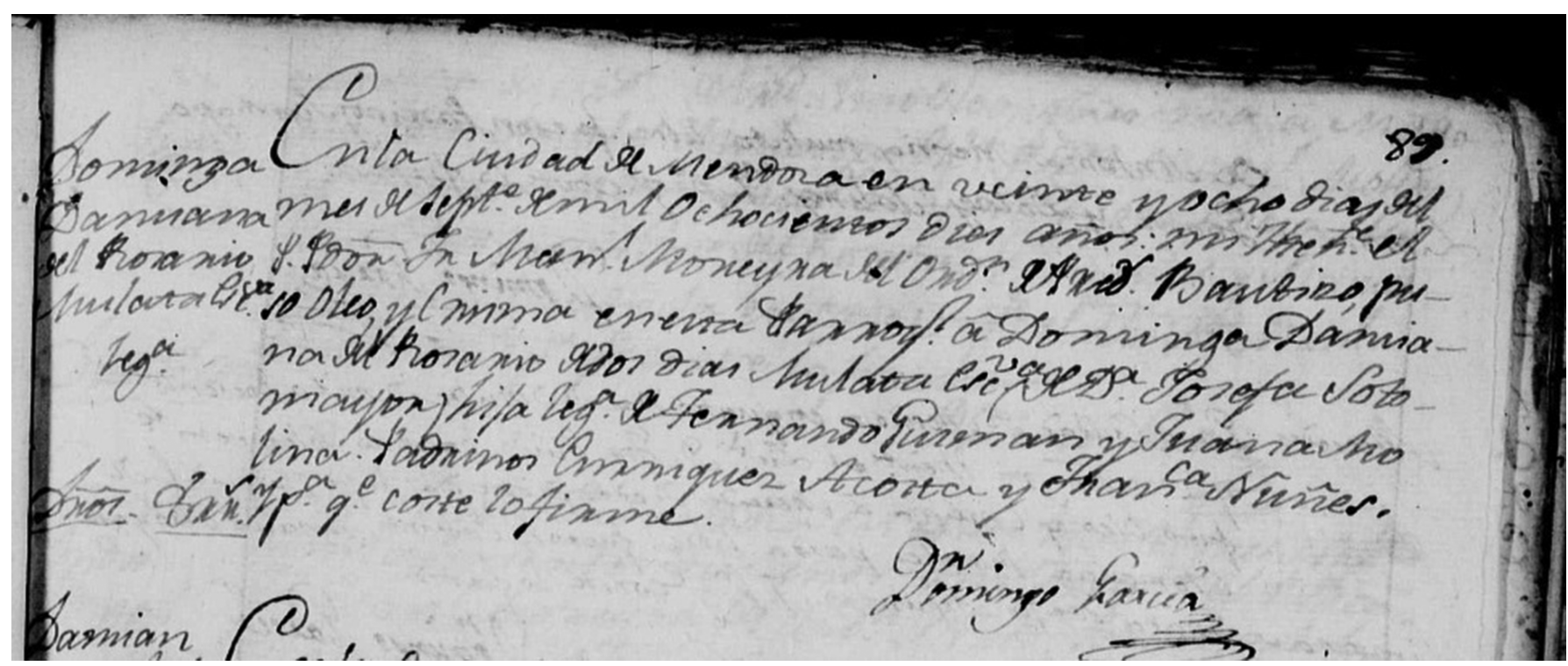

Figure 18. Folio 89 of 28 September 1810.

Dominga became an accomplished pianist and teacher. Dominga was first married to Isidro Ruedas and they had at least one child. Dominga later married Francisco Oliva and they were the parents of eight children. Francisco Oliva was also an accomplished musician and teacher of music, having spent time forming the band of the $4^{\text {th }}$ Battalion and participating in the Chilean independence War. ${ }^{47}$

Merino $^{48}$ relays that several of Fernando Guzman daughters were accomplished musician, adding and remarking about Dominga:

"Dominga Guzmán (married to Isidro Ruedas) was appointed as from 22 October 1857, a professor at the National Conservatory of Music, in the vacant left by Tulio Eduardo Hempel and, according to Luis Sandoval, she "had several good disciples, many of them teachers or assistants from the same establishment."

Dominga later on, became an academic at the National Conservatory of Music. Chile de Ayer ${ }^{49}$ in regards to Dominga's post at the National Conservatory of Music, indicates that:

"...That last year (1857) are hired Francisco Guzmán (for the string chair) and Dominga Guzmán (piano), for the resignations of its predecessors."

\section{Encarnación}

Encarnación was born in Mendoza 24 March 1813, after the new Libertad del Vientre Law was implemented. She was the first of the Guzmán Molina family to be born free. The documents of her baptism dated 28 March $1813^{50}$ indicate that Encarnación was four days old, a free parda, and a legitimate daughter of Fernando Guzmán and Juana Molina. Godparents were Enrique Acosta and Francisca Núñez. Figure 19 shows Folio 154 of 28 March 1813: 


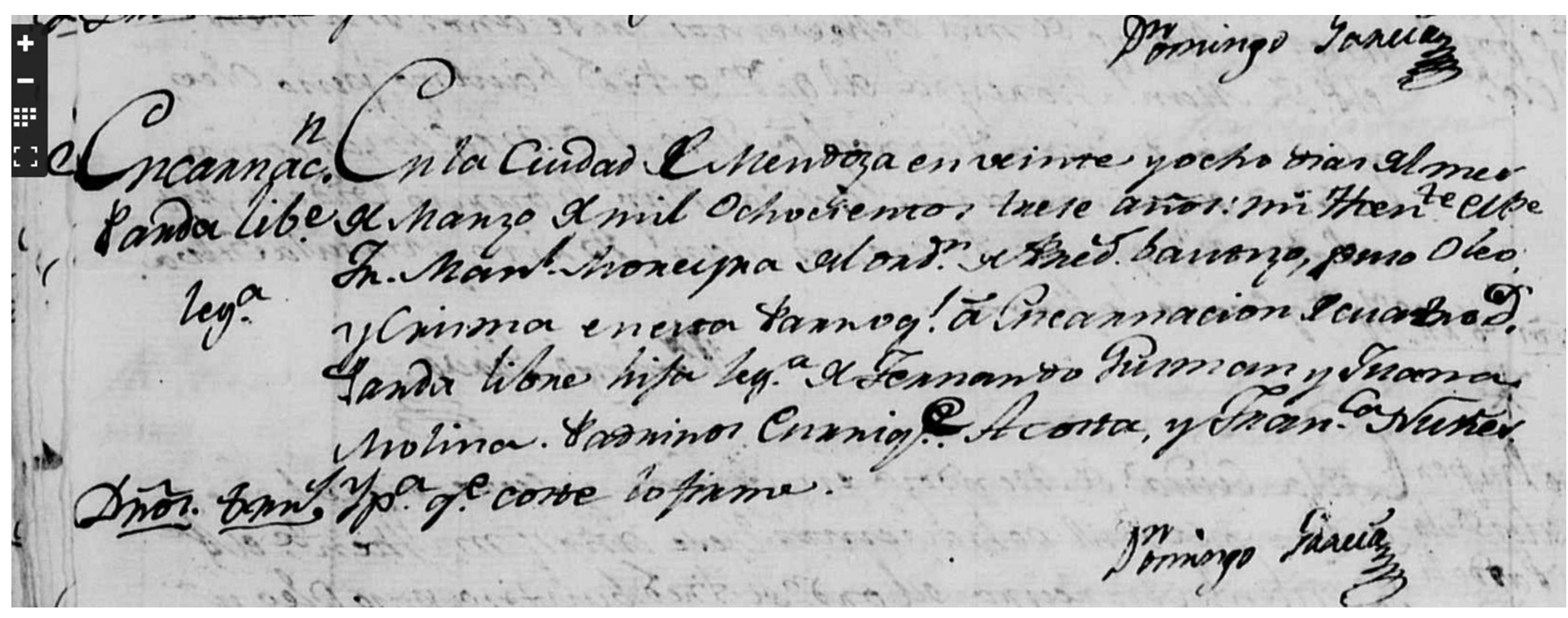

Figure 19. Folio 154 of 28 March 1813.

But Encarnación's life was very short and she died at age 4 years and 7 months old 24 October 1817. Her death documents dated 24 October $1817^{51}$ indicates Encarnación, was a legitimate daughter of Fernando Guzmán and Juana Molina, and was a 4-year-old parda. Figure 20 shows Folio 49 of 24 October 1817:

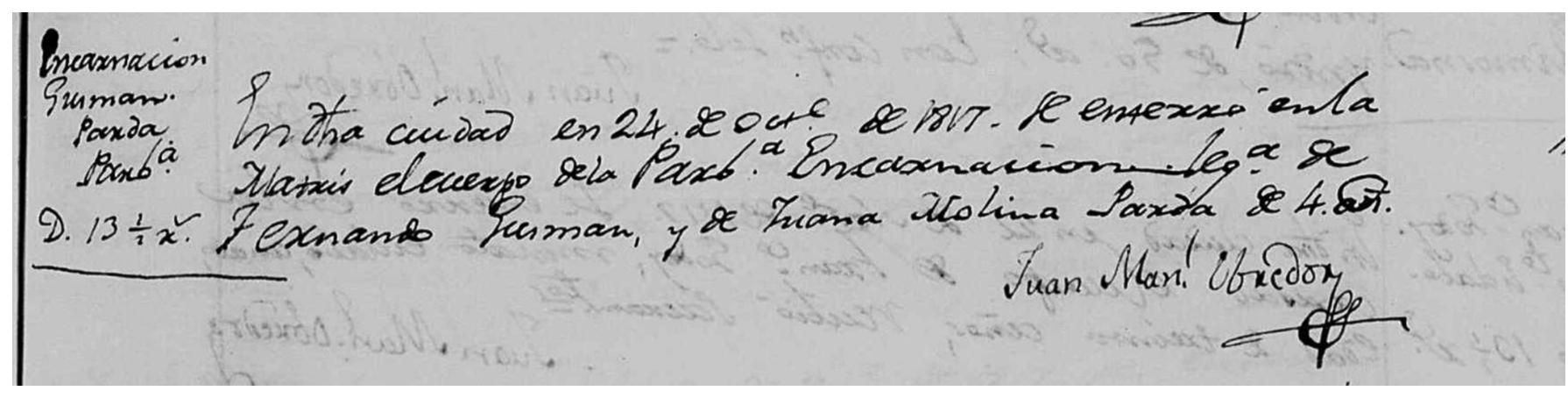

Figure 20. Folio 49 of 24 October 1817.

\section{Eustaquio}

Family records indicate that Eustaquio was born in Mendoza 7 May 1814. No record of Eustaquio's baptism has been found, as the book volume of the baptismal records between 9 May 1814 and 15 November 1814, is missing. Eustaquio was born a couple of days before those dates, but the date of his baptism is unknown, which was most likely during that period, as almost all of his siblings were baptized within the first week of their birth. The names of Eustaquio's parents were confirmed by information from his Death Registry records entry.

As mentioned previously under section Francisco del Carmen, Merino's $\mathrm{s}^{52}$ comments quoting Zapiola Cortés in regard to the first lyrical company to tour Chile in 1830, indicates that Eustaquio played First Cellist:

"Francisco Guzmán as main violin and as first cello his brother Don Eustaquio."

This indicates that Eustaquio was performing concerts in 1830 at 16 years of age. Zapiola Cortés personally knew the Guzmán's; as mentioned by Merino, Zapiola Cortés organised and directed the orchestra which included some of the Guzmán's as main players.

Eustaquio Guzmán married Josefa Frías at the Santa Ana Parish in Santiago 7 May 1834; ${ }^{53}$ the witnesses were his half-uncle, Melchor Guzmán, his mother, Juana Agustina Molina, Isidro Filomeno and Manuel Tobar. Eustaquio and Josefa were the parents of eight children. 
Merino ${ }^{54}$ indicates that Eustaquio Guzmán was an orchestral musician, and that he specialised in a number of instruments including the Piano and Cello:

"Eustaquio Guzmán was an orchestral musician. Subsequently to his collaboration in the orchestra directed by Zapiola in 1830, reference to his participation in July 1839 as a cellist in the orchestra of the Cathedral of Santiago, and in March 1847 he became part of the chapel music group of the Cathedral, lead by his friend José Bernardo Alzedo, in which Zapiola acted as the first violin. He was also a prominent private professor of piano, and as a performer he was still active in 1866, when he participated on July 6 of that year in one of the concerts given by Louis Moreau Gottschalk in Santiago, After 1866, Eustaquio Guzmán served as a teacher of the Conciliar Seminary, and around 1871 he moved to Valparaiso."

Eustaquio died in Valparaíso in 1890, and documentation of his death confirmed that his parents were Fernando Guzmán and Juana Molina, estimating that he was born in 1812 and that he was 78 years old when he died. The Death Register 10 October $1898^{55}$ indicates his name as Eustaquio Guzmán Molina, married to Josefa Oliva, with the profession of Professor, of Argentine nationality, seventy-eight years old, domiciled at Calle Chacabuco 13, and died on the 9 of October at five in the afternoon, of Generalised Artery Sclerosis, at the indicated address. It also indicates that the cemetery where he was to be buried would be the Second Cemetery. Figure 21 shows Death Register of 10 October 1898:

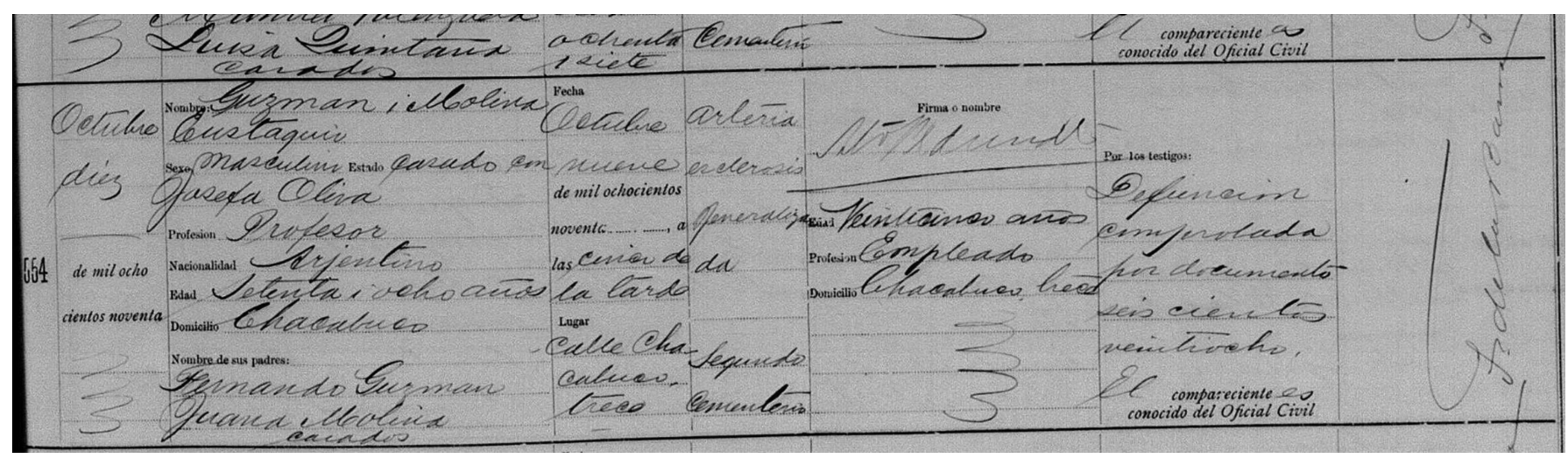

Figure 21. Death Register of 10 October 1898.

The person that made the declaration, whose last name appears to be Aldúnate in the signature, was twenty-five years old, an employee, domiciled at Calle Chacabuco 13 (Eustaquio's address), gave Eustaquio's age as approximately 78 years; the wife's surname was given incorrectly, giving it as Oliva, instead of Frías. Oliva was the surname of his son, Eustaquio Segundo Guzmán's, first wife.

\section{Paula}

Paula was born in Mendoza 17 June 1815. The documents of her baptism dated 22 June $1815^{56}$ records Paula as a five days old mulata, a legitimate child of Fernando Guzmán and Juana Molina. the Godparents were José María Allende and Justina Morales. Figure 22 shows Folio 208 of 22 June 1815 and it reads: 


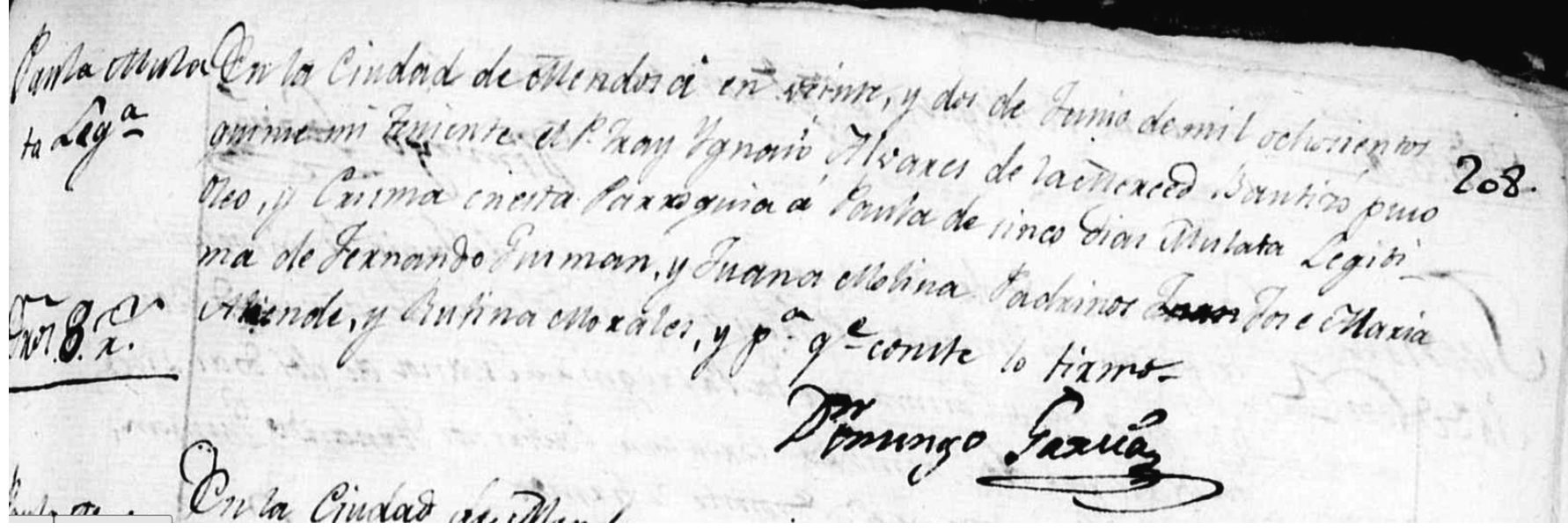

Figure 22. chr Folio 208 of 22 June 1815.

Paula married Pedro Vaché and they were the parents of four children.

Paula was a pianist and a music teacher. Merino ${ }^{57}$ informs that Paula, as a Pianist Teacher, concentrated her efforts of teaching Piano entirely in a private environment, indicating:

"Carmen Guzmán and Paula Guzmán developed teaching exclusively privately."

\section{Víctor Cesareo}

Víctor was born in Mendoza 24 February 1817. The documents of his baptism which is dated 27 February $1817^{58}$ indicates that Víctor Cesareo was three-days old, and a mulato legitimate son of Fernando Guzmán, a Pardos Civicos Officer, and Juana Molina. Figure 23 shows Folio 39 of 27 November 1817:

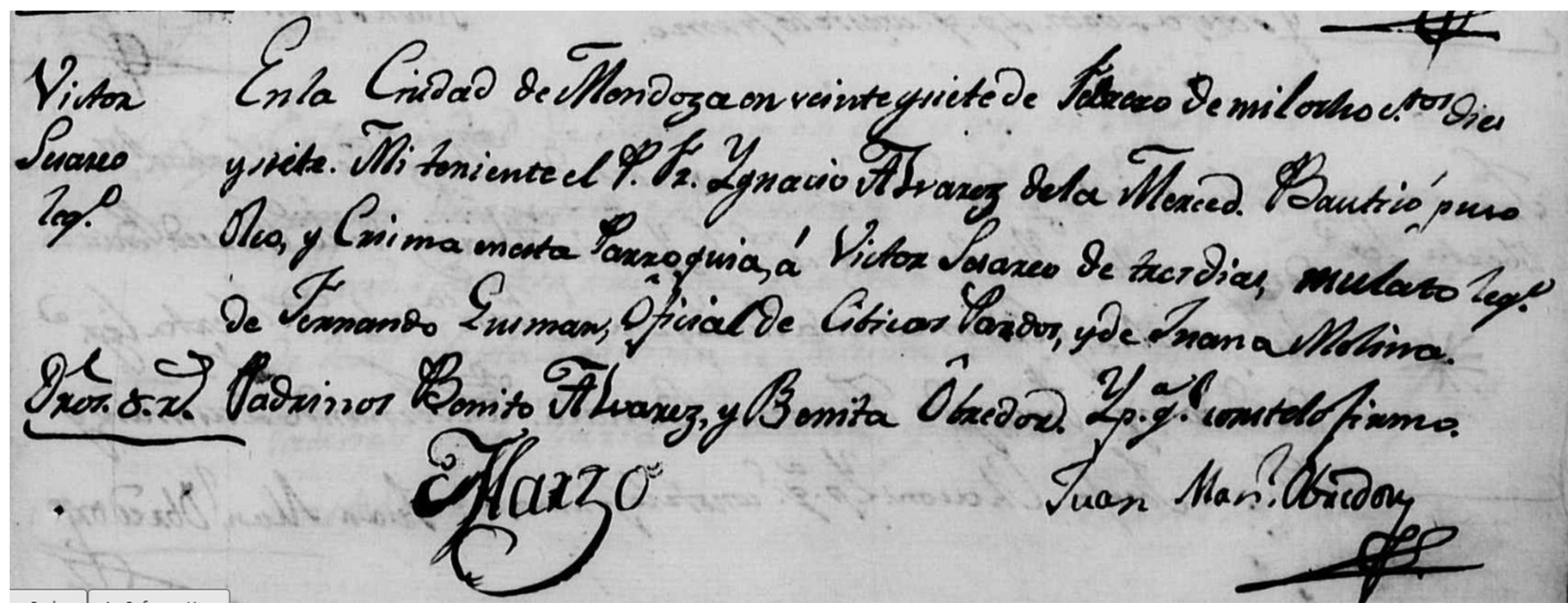

Figure 23. Folio 39 of 27 November 1817.

It is mentioned in the document that Fernando Guzmán was a Pardos Civic Officer; this confirms that Fernando had joined the militia army formed by General José de San Martin. As indicated previously, San Martin offered all slaves their freedom when they served their time in the militia corps.

Pereira Salas ${ }^{59}$ indicates that Víctor was a violinist and toured South America giving concerts: 
"Victor arrived in Chile with his father at the age of five. He studied violin and piano under the direction of his brothers Francisco and Eustaquio, and it was perfected with Bazzini. He made his debut as 19 years old in Valparaíso in 1836, obtaining resounding successes. He played in the Cathedral of Santiago and as the First Violin of the Opera orchestra. In 1853 he went on an American tour. He toured the Argentine cities, Uruguay and Brazil. He settled in Rio de Janeiro in 1860. He lived there in 1872."

According to Otero, ${ }^{60}$ Víctor Guzmán was known as the best Violinist in America in the $19^{\text {th }}$ century, a standing he achieved as a $20-y e a r$ old:

"Victor....Another son of Fernando who stood out for his extraordinary gifts. He was known as the best violinist in America in the last century, a reputation he acquired when he was only 20 years old in 1838, at the time of his father's death. He was a musician for the Cathedral of Buenos Aires and the Theatre of Santiago...."

Victor died in Rio de Janeiro, Brazil in about 1882.

\section{María del Carmen}

Carmen was born in Mendoza 5 August 1818. The documents of her christening dated 14 August $1818^{61}$ indicate that María del Carmen, was nine-days old española legitimate of Fernando Guzmán and Juana Molina. Godparents were Eugenio Calbo and Manuela Cárdenas. Figure 24 shows Folio 108 of 14 August 1818:

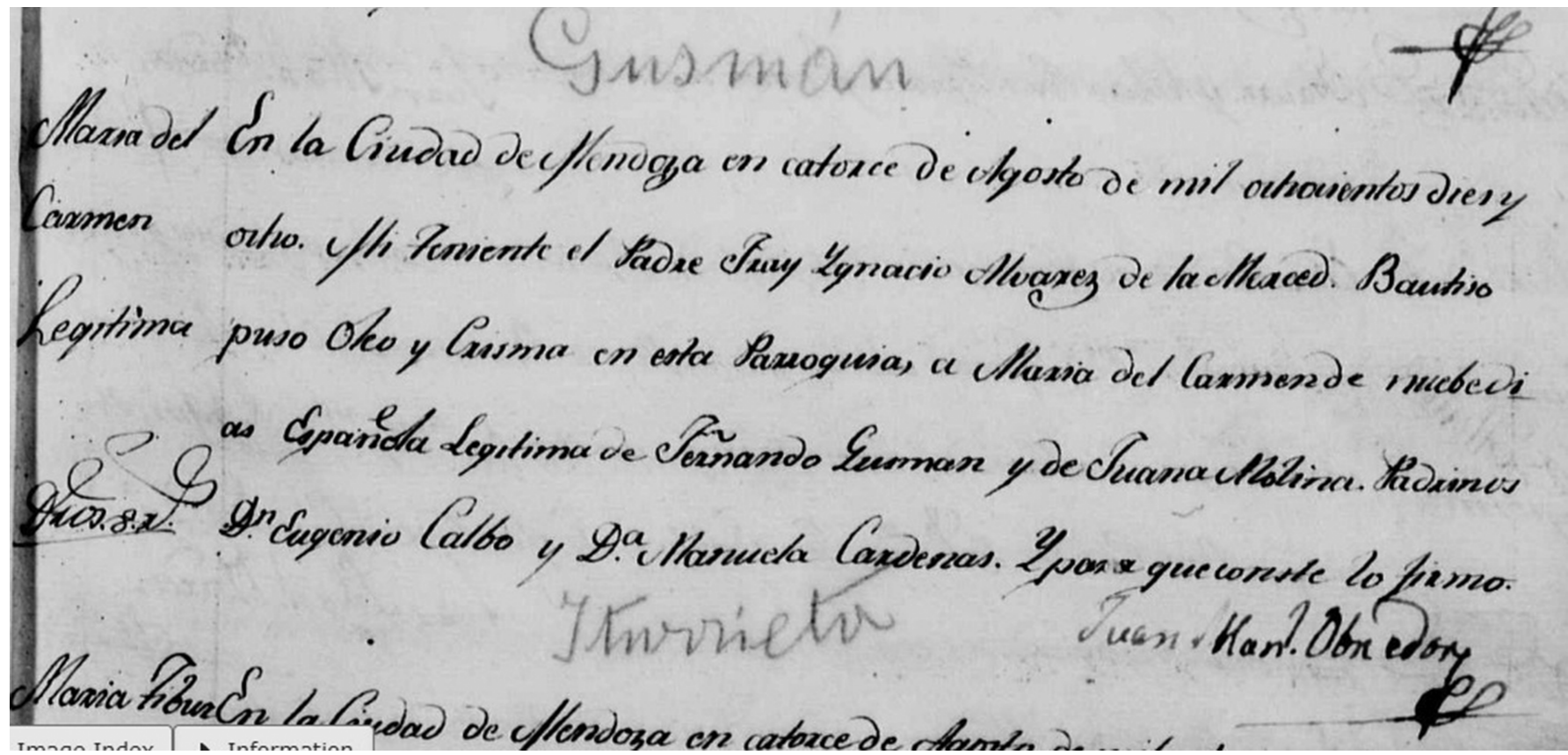

Figure 24. Folio 108 of 14 August 1818.

Carmen married José Dolores Fuenzalida and they were the parents of four children.

Carmen was a pianist and a music teacher. Merino ${ }^{62}$ informs that Carmen, as a piano teacher, concentrated her efforts of teaching piano entirely in a private practice:

"Carmen Guzmán and Paula Guzmán developed teaching exclusively privately."

\section{María del Rosario}

Rosario was born in Mendoza 16 January 1821. The documents of her baptism dated 20 January $1821^{63}$ indicate: María del Rosario was four days old, and a parda legitimate daughter of Fernando Guzmán and Juana Molina. Godparents were Seledonio Campos and María del Carmen Calbo. Figure 25 shows Folio 144 of 20 January 1821: 


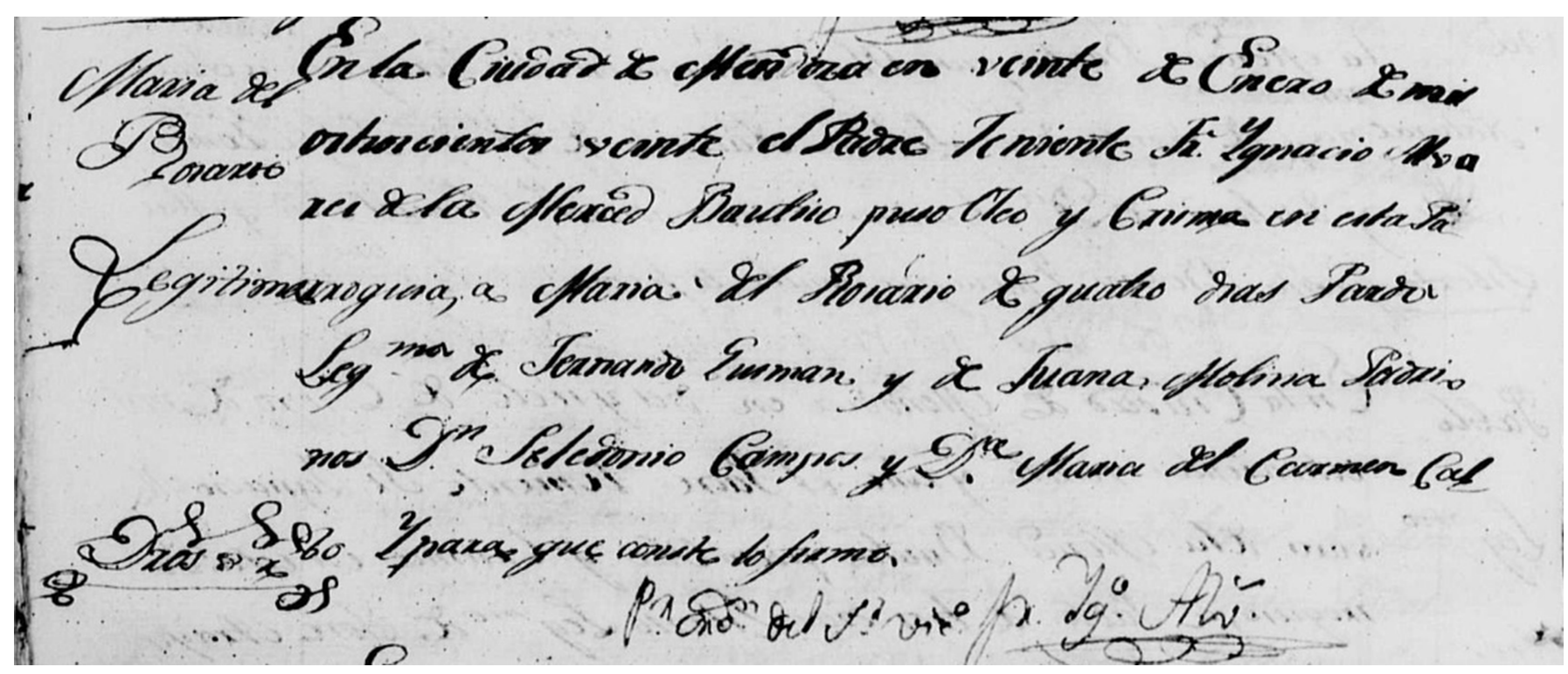

Figure 25. Folio 144 of 20 January 1821.

Rosario married José Manuel Rivas, a military officer in the Peruvian Army and they were the parents of four children. José Manuel Rivas died in 1860.

Rosario was a pianist and a piano teacher. Milanca Guzmán ${ }^{64}$ relates that Rosario was the widow of José Manuel Rivas, and that after his death, Rosario returned to teaching Piano at the National Conservatory of Music:

"The Guzmán family was present on the pedagogical scene with several of its members: ... and Rosario, who in 1860 offered her services as an" old piano teacher." We know that she was the widow of Sergeant Major of the Peruvian Army José Manuel Rivas. In January 1861- she traveled to that country to collect the montepio, and already in March 1862 she returned to offer herself as a piano teacher in Santiago."

Claro Valdez ${ }^{65}$ indicates that many private piano teachers were teaching piano at the National Conservatory of Music, including Rosario, who has started teaching initially in Santiago but later moved to the Valparaiso Conservatory:

\footnotetext{
"Among the private teachers who stood out in the country, many of whom went to teach at the Conservatory, Jules Bard, one of the pioneers of piano teachingAdolfo Desjardins and Eustaquio $2^{\circ}$ Guzman. In Valparaiso were the piano teachers Rosario Guzman and Adolfo Yentzen."
}

Rosario died in Quillota, Valparaíso, 17 June 1893 at the age of 72 years and five months.

\section{Fernando}

Fernando was born in Santiago, Chile in October 1824, the only of the Guzmán Molina children to be born there. The documents of his baptism are dated 19 October $1824,{ }^{66}$ and indicate that his parents were Fernando Guzmán and Juana Molina. The Christening was at El Sagrario in Santiago. There is no image of the baptism document, but the entry in the records of copies of certificates refers to the event. Figure 26 shows the Baptism entry of 19 October 1824: 


\section{Fernando Guzman}

Chile Baptisms

\begin{tabular}{ll} 
Name & Fernando Guzman \\
\hline Gender & Male \\
\hline Christening Date & 19 Oct 1824 \\
\hline Christening Place & $\begin{array}{l}\text { El Sagrario, Santiago, } \\
\text { Santiago, Chile }\end{array}$ \\
\hline Father's Name & Fernando Guzman \\
\hline Mother's Name & Juana Molina
\end{tabular}

Chile Baptisms, 1585-1932

Indexing Project (Batch) Number

\section{System Origin}

GS Film number
C62103-7

Chile-

EASy

797302

Figure 26. Baptism entry of 19 October 1824 .

No additional information was found about Fernando.

\section{Possible Additional Child}

The possible existence of a fourteen child of Fernando and Juana Agustina, as mentioned by Caballero, ${ }^{67}$ of a child by the name of Domingo born between Dominga and Encarnación. There is a 2-year 5 month gap between the births of Dominga, born in September 1810, and Encarnación, born in March 1813, but no details were either found by Caballero. Caballero indicates:

"Domingo Guzman - No baptism certificate has been found, it is estimated that he was born in this period."

No details or evidence of Domingo's existence have been found during this investigation of birth, baptism and death records, searching the records manually for the 24-year period between 1800 and 1824.

\section{Final Note}

Fernando was considered one of the most important classical musicians in Chile during the $19^{\text {th }}$ century. García Arancibia ${ }^{68}$ indicates the effect of the arrival in Chile of musicians like Fernando Guzmán, recounting:

\footnotetext{
"Shortly after independence, we found important foreign musicians in Chile doing commendable educational work. In 1822, Fernando Guzmán, an excellent pianist, father of Eustaquio, one of the first music publishers in the country, and grandfather of Federico, pianist and composer, arrived in the country from Mendoza, Argentina, undoubtedly one of the most important Chilean musicians of the last century....."
}

According to Otero, ${ }^{69}$ when discussing Victor Guzmán as the best violinist in America in the $19^{\text {th }}$ century, he indicated that Fernando died in about 1838:

\footnotetext{
"Victor... was known as the best violinist in America in the last century, a reputation he acquired when he was only 20 years old in 1838 , at the time of his father's dead."
}

It is known that Fernando Guzmán died in Santiago in 1839. The last recorded information of his wife, Juana Agustina, was as a witness of their son Eustaquio's wedding in May 1834. There is no established information on the death of Juana Agustina Molina.

\section{Conclusion}

This investigation confirms that Fernando Guzmán, born a slave of the Dominican Convent, was the father of thirteen children, six of them slaves of the Molina Sotomayor family, seven born in freedom.

Fernando Guzmán learnt to play the piano and violin at an early age and was giving concerts and earning his keep early in life. At age 24 he was able to, with money earned from his trade, free his own enslaved son, Francisco, out of slavery. He ensured all his children became proficient in playing a number of different instruments, including the piano and the violin, among others. 
The investigation also confirms that Fernando Guzmán and Juana Agustina Molina, both of African descent and born into slavery, were the parents of at least thirteen children. Twelve of them were born in Mendoza and the first six were born into slavery. The next six were born free, after the Libertad del Vientre Law was introduced there in 1813. The youngest one was born after they arrived in Chile, thus also born free.

The records now indicate that of the 13 children, one of them, the eldest, Justa del Carmen, is unaccounted for and presumed died after the 1802 Parish Census was taken, but before the 1814 Parish Census was taken.

Four of the other children died in Mendoza either in infancy or at a young age. Genaro Eustaquio died in 1809 age 3-years and 3 months; Maria Gertrudes died in 1810 age 1-year and 9 months; Encarnación died in 1817 age 4-years and 7 months; and Bernardina died in 1818 age 13-years.

It can now be assumed that Fernando Guzmán and Juana Agustina Molina arrived in Chile with seven of their children, the eldest already an adult, and their last child was born soon after their arrival, establishing their new family home of ten, and perhaps eleven, if Fernando's mother, María Juana, came with them.

The arriving group comprised of 44-year old Fernando, 41-year old Juana Agustina, 20-year old Francisco, 12-year old Dominga, eight-year old Eustaquio, seven-year old Paula, five-year old Victor, four-year old Carmen and one-year old Rosario; they were joined in 1824 by Fernando. No documented evidence was found regarding María Juana. It is assumed that María Juana died in Chile after the family arrived there.

The Guzman contributed to the music environment of the epoch, each in his own way. Their accomplishments can be mentioned as:

Fernando Guzmán - Fernando was an excellent pianist, violinist and Orchestral Director as well as a teacher, the Johann Sebastian Bach of Spanish America. Fernando was the first teacher who made students study scales and exercise, teaching first in Mendoza and then in Chile. Fernando was one of the most important classical musicians in Chile during the $19^{\text {th }}$ century;

Francisco Guzmán Molina - Francisco was an outstanding violinist and pianist and acted as First Violin in many concerts. Married Carmen Sanchez, also an acclaimed Pianist, and both, in 1826, were members of the Orquesta de la Sociedad Filarmónica de Santiago. Francisco was appointed Professor of Strings at the Conservatorio Nacional de Música;

Dominga Guzmán Molina - Dominga was a pianist. She married Francisco Oliva, an accomplished musician and music teacher. Dominga was appointed a Piano Professor at the Conservatorio Nacional de Música;

Eustaquio Guzmán Molina - Eustaquio was an orchestral musician, specialised in piano and cello. Was a violoncellist at the Santiago Cathedral, a private piano teacher, and a music teacher of the Concilia Seminary. He was also a Lithographer, one of the first music publishers in the country;

Paula Guzmán Molina - Paula was a violinist and pianist, and a private music teacher. Paula married Pedro Vaché;

Victor Guzmán Molina - violinist, composer and teacher of several instruments, Víctor was said to be the best violinist in Spanish America in the $19^{\text {th }}$ century;

Carmen Guzmán Molina - Carmen was a pianist and a private music teacher. Carmen married José Dolores Fuenzalida;

Rosario Guzmán Molina - Rosario was professor at the National Conservatory of Music and a private piano teacher. Rosario married José Manuel Rivas;

Fernando Guzmán Molina - No further information is available regarding Fernando.

There was never any doubt that the Guzmán's were a family of classical musicians par excellence. Not only Fernando Guzmán, as the head of the family, but also his children, and many of his grandchildren, are all well recognised as excellent musicians. The Guzmán's not only excelled in playing, teaching, composing music and being academics in the field of music, but also some of them were involved early in the field of lithographic printing of musical material. 


\section{Future Research}

The origins and composition of the Guzmán family have now been confirmed; Fernando, originally a slave, was the father of at thirteen children and the grandfather of at least thirty-eight grandchildren.

It is proposed that future research will contribute by expanding the discoveries and reporting into all the other members of the Guzman family. These would include the families of the all the children and the grandchildren of Fernando Guzmán, many of whom became accomplished classical musicians themselves, will be explored and reported in detail.

\section{Contribution}

There is a need to mention and to thank Luis César Caballero, Genealogical Writer and Researcher based in Mendoza, Argentina, who wrote Los Negros esclavos en Mendoza, algunas genealogías, published in 2010, in which he describes Fernando Guzmán and his family, providing the basis for this investigation. Subsequently, Luis Cesar has been a strong source of inspiration, information and has contributed material used in this investigation. His work and help has been very welcome and much appreciated.

\section{References}

1. Otero, Higinio (1970) Musica y musicos de Mendoza - Desde sus orígenes - hasta nuestro dias, p. 67.

2. Fernando Guzman invoice - 14 January 1806, Argentina, Distrito Federal, Buenos Aires, registros notariales, 1780-1963. Familysearch № Microfilme 103935003 Imagen 539

3. Otero, op. cit. p. 68

4. Zapiola Cortés, José (1872) Recuerdos de treinta años, p. 39.

5. Caballero, Luis Cesar (2010) Los Negro esclavos en Mendoza, algunas genealogías, in Cuadernos de Genealogía de Cuyo, p. 70

6. Merino, Luis (1993) Tradición y modernidad en la creación musical: la experiencia de Federico Guzmán en el Chile independiente (Primera Parte), https://revistamusicalchi lena.uchile.cl/index.php/RMCH/article/view/1677, downloaded on 22 November 2017, p. 10.

7. Merino, op. cit. p. 11

8. Morales Guiñazú, Fernando (1940) La música en Mendoza. Mendoza: Best hermanos, p. 6.

9. Morales Guiñazú, Fernando (1943) Historia de la cultura mendocina. Mendoza: Best hermanos, p. 469

10. Suárez, José Bernardo (1872) Plutarco del jóven artista, in Biblioteca de la Juventud.

11. Gazualdo, Vicente (1961) Historia de la música en la Argentina, p. 311.

12. Otero, op. cit. p. 74-77.

13. Merino, op. cit. p. 13

14. Caballero, op. cit. p. 75

15. García Arancibia, Fernando (1991) Domingo Brescia y el aporte foráneo al desarrollo musical chileno, Revista Musical Chilena, Año XLV, enero-junio, N" 175, p. 42-56.

16. Merino, op. cit. p. 10

17. Hernandez C., Roberto (1927) Una reseña histórico local, con motivo del Centenario de "EL MERCURIO, en Valparaiso en 1827, p. 324

18. Otero, op. cit. p. 74-77.

19. Zapiola Cortés, op. cit. p. 38.

20. Pereira Salas, Eugenio (1978) Biobibliografia Musical de Chile - desde los orígenes a 1886, p. 72-82

21. Zapiola Cortés, op. cit. p. 38.

22. ANC, La abolición de la esclavitud en Chile, 11 de octubre de 1811, in Archivo Nacional de Chile,https://www.archivonacional.gob.cl/616/w3-article-8084.html? _noredirect=1\#: : text=La\%20ley\%20de\%20Libertad\%20de,quedaban\%20autom\% C3\%A1ticamente\%20libres\%20al\%20nacer,Downloaded 11 November 2017.

23. Murcia, Diego Gonzalo, La Asamblea del Año XIII y el problema de la esclavitud AEQUITAS-Virtual, Vol. 7, Núm. 20, 2013, p 1, https://p3.usal.edu.ar/index.php/aequi tasvirtual/article/view/2073/2604, Downloaded 20 Nov 2018

24. Suárez, op. cit. p. 397.

25. Protocolo № 144, escribano Cristóbal Barcala, año 1802, folios 137 a 139. Mendoza, 24 de Diciembre de 1802.

26. Mallo, Silvia C., La libertad en el discurso del Estado, de amos y esclavos. 1780-1830, referring to "A.H.P.B.A. Real Audiencia 5-3-4-41, 1811", 1991.

27. Carpeta № 457, independiente, Listas Militares, años 1816/1829, documento № 14 Fuerza empleada en la guarnición de esta Plaza. Mendoza, 6 de Febrero de 1817.

28. Argentina, Mendoza, registros parroquiales, 1665-1975, database with images, Familysearch (https://familysearch.org/ark:/61903/3:1:939F-VSNP-T?cC= 1974189\&wc=Q633-38Y\%3A256821101\%2C256946201\%2C256977001: 18 March
2017), Mendoza > San Nicolás de Tolentino > Bautismos 1807-1822 > image 448 of 869; parroquias Católicas (Catholic Church parishes), Mendoza.

29. Historia de la esclavitud en Argentina, Ministerio de Cultura, Argentina, 19 de Octubre de 2017, https://www.cultura.gob.ar/historia-de-la-esclavitud-en-argen tina_4933/, Downloaded 17 January 2018.

30. Argentina, Mendoza, registros parroquiales, 1665-1975," database with images, FamilySearch (https://familysearch.org/ark:/61903/1:1:XNJW-WRQ: 18 March 2017), Fernando, Baptism 06 Dec 1778.

31. Argentina, Mendoza, registros parroquiales, 1665-1975," database with images, FamilySearch (https://familysearch.org/ark:/61903/1:1:XNJ CQV: 9 March 2018), Juana Agna, Baptism 24 Jun 1781.

32. Argentina, Mendoza, registros parroquiales, 1665-1975," database with images, FamilySearch (https://familysearch.org/ark:/61903/1:1:QVN9-H5JV: 11 January 2017), Fernando Guzmán and Juana Agustina Borja, Marriage 24 Jun 1799.

33. Argentina, Mendoza, registros parroquiales, 1665-1975," database with images, FamilySearch (https://familysearch.org/ark:/61903/1:1:XNJ8-Y5V: 18 March 2017), Justa del Carmen Guzmán, Baptism 30 May 1800.

34. Caja № 38, carpeta 7.21.4, № 2273. Archivo del Arzobispado de Mendoza.

35. Argentina, Mendoza, registros parroquiales, 1665-1975," database with images, FamilySearch (https://familysearch.org/ark:/61903/1:1:XNJD-MXF: 18 March 2017), Francisco del Carmen Gusman, Baptism 15 Jul 1802.

36. Protocolo № 144, escribano Cristóbal Barcala, año 1802, folios 137 a 139. Mendoza, 24 de Diciembre 1802.

37. Merino, op. cit. p. 12.

38. Neuma, Revista de Música y Docencia Escuela de Música - Universidad De Talca Año 2, 2009, p. 27.

39. Hernandez C, Roberto, (1927) Una reseña histórico local, con motivo del Centenario de "EL MERCURIO, in Valparaiso en 1827, p. 323-324, http://www.schhg.cl/wpschhg/2019/02/25/valparaiso-en-1827-de-roberto-hernandez-c/, downloaded 28 November 2018.

40. Argentina, Mendoza, registros parroquiales, 1665-1975," database with images, FamilySearch (https:/familysearch.org/ark:/61903/1:1:XNJ3QH: 9 March 2018), Bernardina Gusman, Baptism 20 May 1804.

41. Argentina, Mendoza, registros parroquiales, 1665-1975", database with images, FamilySearch (https://www.familysearch.org/ark:/61903/1:1:Q847B: 4 June 2020), Bernardina Molina,1818.

42. Argentina, Mendoza, registros parroquiales, 1665-1975," database with images, FamilySearch (https:/familysearch.org/ark:/61903/1:1:XNJD-WLQ: 18 March 2017), Genaro Eustaquio Gusman, Baptism 20 Sep 1806.

43. Argentina, Mendoza, registros parroquiales, 1665-1975", database with images, Family Search (https://www.familysearch.org/ark:/61903/1:1:QVN9-87PK: 4 June 2020), Eustaquio, 1809.

44. Argentina, Mendoza, registros parroquiales, 1665-1975," database with images, FamilySearch (https://familysearch.org/ark:/61903/1:1:XNJZ-XYF: 18 March 2017), María Getrudes Gusman, Baptism 17 Nov 1808.

45. Argentina, Mendoza, registros parroquiales, 1665-1975", database with images, FamilySearch (https://www.familysearch.org/ark:/61903/1:1:QVN9-87RY: 4 June 2020), Getrudes Sotomayor, 1810.

46. Argentina bautismos, 1645-1930", database, FamilySearch (https://familysearch.org/ ark:/61903/1:1:XNJZ-J2P: 13 February 2020), Dominga Damiana Guzmán, Baptism 28 Sep 1810 
47. Aguilera Mardones, Santiago (2007) Música en tiempos de la Emancipación.

48. Merino, op. cit. p. 13

49. Chile de Ayer, National Conservatory of Music and Declamation of Santiago, https://www.facebook.com/Chiledelayer Pagina Oficial, accessed on 28 November 2018.

50. Argentina, Mendoza, registros parroquiales, 1665-1975," database with images, FamilySearch (https://familysearch.org/ark:/61903/1:1:XNJZ-2BM: 18 March 2017), Encarnación Guzmán, Baptism 28 Mar 1813.

51. Argentina, Mendoza, registros parroquiales, 1665-1975", database with images, FamilySearch (https://www.familysearch.org/ark:/61903/1:1:QVN9-8WTS: 4 June 2020), Encarnacion Guzman, 1817.

52. Merino, op. cit. p. 13-14.

53. Parroquia de Santa Ana, Libro SOJ de Matrimonio, tomo VI, 1824-1839, fol.90v, Santiago

54. Merino, op. cit. p. 13.

55. Chile, Registro Civil, 1885-1932, database with images, FamilySearch (https://famil ysearch.org/ark:/61903/1:1:Q2SG-KB6H: 10 April 2020), Eustaquio Guzmán Molina, Death 09 Oct 1890

56. Argentina, Mendoza, registros parroquiales, 1665-1975," database with images, FamilySearch (https:/familysearch.org/ark:/61903/1:1:XNJZ-5ML: 18 March 2017) Paula Gusman, Baptism 22 Jun 1815
57. Merino, op. cit. p. 14.

58. Argentina bautismos, 1645-1930", database, FamilySearch (https://familysearch.org/ ark:/61903/1:1:XNJ8-45S: 13 February 2020), Víctor Suárez, Baptism 27 Feb 1817.

59. Pereira Salas, op. cit. p. 80

60. Otero, op. cit. p. 74-75.

61. Argentina, Mendoza, registros parroquiales, 1665-1975," database with images, FamilySearch (https://familysearch.org/ark:/61903/1:1:XNJC-MMP: 18 March 2017), María del Carmen Gusman, Baptism 14 Aug 1818.

62. Merino, op. cit. p. 14

63. Argentina, Mendoza, registros parroquiales, 1665-1975," database with images, FamilySearch (https://familysearch.org/ark:/61903/1:1:XNJ8-63P: 18 March 2017), María del Rosario Gusman, Baptism 20 Jan 1821.

64. Milanca Guzmán, Mario, La música en el periódico chileno "El Ferrocarril" (1855-1865), p11, Rev. music. chil. v.54 n.193, Santiago Jan 2000

65. Claro Valdez, Samuel (1979), Oyendo a Chile, p. 79

66. Chile, bautismos, 1585-1932," database, FamilySearch (https://familysearch.org/ark:/ 61903/1:1:FJXY-B26: 3 December 2014).

67. Caballero, op. cit. p. 77

68. García Arancibia, op. cit. p. 44.

69. Otero, op. cit. p. 74-75.

\section{ABOUT THE AUTHOR}

William M. Guzman was born Santiago, Chile. As a young adult he migrated to Australia and graduated in IT from CDI in Sydney. William holds a Graduate Diploma and a Master Degree in Logistics, a Master Degree in Commerce, and a PhD in Business Information Systems. He is currently an Academic at a university in Melbourne. He has conducted genealogy research for the last 30 years. (D) 